\title{
Mapping of Precipitation, Temperature and Evaporation Distributions in the Porsuk Basin Using Distant Forecasting Methods
}

\author{
Recep Bakış¹, Yıldırım Bayazıt², Hakan Uyguçgil ${ }^{1}$, Cengiz Koç ${ }^{3^{*}}$ \\ ${ }^{1}$ Department of Civil Engineering, Anadolu University, Eskişehir, Turkey \\ ${ }^{2}$ Department of Civil Engineering, Bilecik Şeyh Edebali University, Bilecik, Turkey \\ ${ }^{3}$ Department of City and Regional Planning, Faculty of Architecture, Muğla Sitkı Koçman University, Muğla, Turkey \\ Email: rbakis@anadolu.edu.tr,yildirim.beyazit@bilecik.edu.tr,huygucgil@anadolu.edu.tr, *cengizko9@gmail.com
}

How to cite this paper: Bakış, R., Bayazıt, Y., Uyguçgil, H. and Koç, C. (2017) Mapping of Precipitation, Temperature and Evaporation Distributions in the Porsuk Basin Using Distant Forecasting Methods. Computational Water, Energy, and Environmental Engineering, 6, 321-350. https://doi.org/10.4236/cweee.2017.64021

Received: March 28, 2017

Accepted: September 3, 2017

Published: September 7, 2017

Copyright $\odot 2017$ by authors and Scientific Research Publishing Inc. This work is licensed under the Creative Commons Attribution International License (CC BY 4.0).

http://creativecommons.org/licenses/by/4.0/

(c) (i) Open Access

\begin{abstract}
Geographical data are of great importance in meteorology and climate science. These data can create the areal distribution models analyzed by spatial interpolation methods. The values of the areas without measurement data are estimated with these distribution models. In this study, distribution of meteorological parameters such as precipitation, temperature and evaporation in Porsuk basin, which is determined as research area, was investigated by Inverse Distance Weighting (IDW) and Ordinary Kriging methods. Actual meteorological data analyzed of the basin do not show a normal distribution statistically. Therefore, the data were firstly subjected to normalization and then analyzed according to the IDW and Ordinary Kriging methods to create distribution maps of precipitation, temperature and evaporation data. Quadratic mean error values were compared to investigate the reliability of analyzes. In this study, the analysis results of precipitation, temperature and evaporation data have been calculated by two different methods. Ordinary Kriging method has been determined as the method making the most accurate estimation.
\end{abstract}

\section{Keywords}

Geographical Information Systems, Inverse Distance Weighting, Ordinary Kriging, Meteorology, Porsuk Basin, Turkey

\section{Introduction}

Water resources need to be managed on a watershed basis and in harmony with other natural resources, while they also need to be consistent with the principle of sustainable development. The basic mean of achieving these conditions is a 
continuously updated and adaptable watershed information system. In our country, the concept and philosophy of "watershed information system" is not yet established. Therefore, even in the initial stage of watershed management, there is a significant shortage [1]. The main target in watershed management is; conservation of natural resources, bringing the environment into a state where it can renew itself, and sustainable management of resources. Geographical Information Systems (GIS) are seen as a technological and indispensable tool for the preparation of the environments necessary for the collection of the data for the basin and its storage in the digital environment [2].

In basin management planning, spatial distributions of climate data can be produced in different layers by using point observation values with the aid of GIS. This situation has made the use of GIS inevitable. If the spatial distribution of climate parameters is to be determined and the corresponding climate layers are produced, it is possible to encounter multiple methods. However, the method suitable for one region is not suitable for another region. For this reason, it is necessary to apply similar studies to each region with different methods depending on the characteristics of the region and the structure of the data [3]. That being the case, the determination of the method which is best suitable for each region or basin becomes a problem.

Evaporation, temperature, precipitation climate data are spotted at meteorological observation stations. Since the data are obtained in this way, they are point-shaped in the basin. Therefore, spatial distributions using point data and climate data need to be generated in different layers in the GIS environment. Thus, relationships between data layers can be investigated and interrogation possibilities can be achieved. In studies on the development of water resources, the average areal precipitation depth over a given area is used instead of point precipitation values [4].

\section{Material and Methods}

In the survey, 250 raster maps (scanned and positioned) and vector (digital map) maps, 106 geological digital maps (with European Datum 1950 (ED50)-UTM $35 \mathrm{~N}-36 \mathrm{~N}$, with $1 / 25,000$ scale covering the Porsuk basin and neighboring basins around the basin Zone coordination system) have been obtained from the III. Regional Directorate of General Directorate of State Hydraulic Works (DSI). From these maps, Digital Elevation Model (DEM) was created. Digital Elevation Models (DEMs) are a type of raster GIS layer. Raster GIS represents the world as a regular arrangement of locations. In a DEM, each cell has a value corresponding to its elevation. The slope, elevation, elevation and relief maps of the basin are derived using the digital elevation model. With hydrological models, hydrological boundaries of the basin and synthetic drainage network have been obtained. The data required to determine the long-run magnitudes of the meteorological characteristics of the basin (evaporation, temperature, precipitation) were obtained from the General Directorate of State Meteorology Affairs (DMI). 
The Meteorological Observation Station (MOS) data are taken as monthly averages covering the years 1991-2011. In the Microsoft Excel environment, the data were analyzed and arranged according to the MOS data of each province. Coordinates of each province are transferred to GIS environment. To be able to predict correctly with a dataset, the dataset must have a normal distribution. When the obtained meteorological data were examined, it was found that they did not show statistically normal distribution. For a normal distribution of a data set, it is necessary that the Skewness coefficient is zero (0) and the Kurtosis coefficient is close to (3). In addition, mean and median values should be close to each other. Some transformations such as $\log , \ln$, $\sin , \cos$, tan, and square root have been applied to normalize the data set to make predictions. These values are used in the estimation process based on the transformations that approximate the normal distribution. However, since the temperature distribution is close to the normal distribution in the original values, no transformation is needed. It is aimed to compare these methods using two distance-dependent methods (IDW, Ordinary Kriging).

\section{Description of the Study Area}

The research area is Porsuk Creek Basin. Porsuk Basin is a sub-basin of the Sakarya basin and has an area of $11,113.66 \mathrm{~km}^{2}$ in northwest Anatolia. The basin lies between $29^{\circ} 38^{\prime}-31^{\circ} 59^{\prime}$ East longitudes and $38^{\circ} 44^{\prime}-39^{\circ} 99^{\prime}$ North latitudes. The basin is $202 \mathrm{~km}$ long in the east-west direction and $135 \mathrm{~km}$ long in the north-south direction (Figure 1). More than $60 \%$ of the basin is mountainous. The surface waters of the Porsuk Basin are collected by the Porsuk Stream and discharge into the Sakarya river at $660 \mathrm{~m}$ elevation, after having traveled $436 \mathrm{~km}$ in the basin.

\section{Determination of Porsuk Hydrological Basin Boundaries by Geographical Information System}

Basin-based meteorological data for Porsuk basin requires estimation of the hydrological boundaries of the basin and analysis of the basin surface for estimation and surface analysis. For this purpose, the characteristics of the basin have been determined with the help of digitized maps. Basin's Digital Elevation Model (DEM) was extracted using 1/25.000 scaled digitized vector maps. The digital elevation model was analyzed by cutting it according to the hydrological basin boundary. The digital elevation model of Porsuk basin and the lower basins are given in Figure 2(a) and Figure 2(b).

\subsection{Determination of the Lower Basins and the Drainage Areas in Porsuk Basin}

The lower basins which make up the main basin have been created from the hydrological analysis based on the digital elevation model. Also by using the digital elevation models, the slope, height and the three dimensional maps have been 


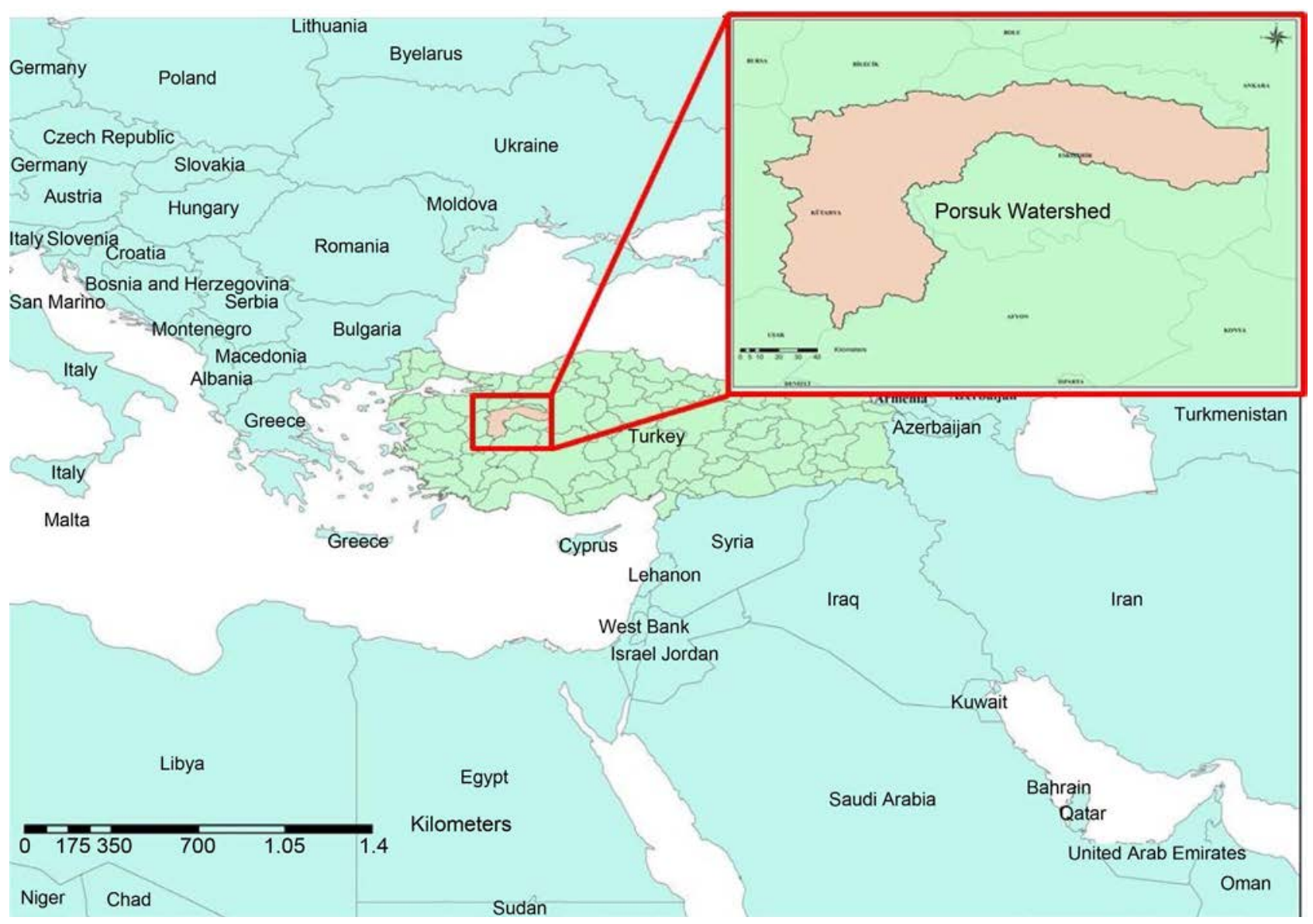

Figure 1. Location of Porsuk basin in Turkey.

derived from CBS environment. Again by using the numerical height model, the drainage area and the boundaries of the lower basins and the flow direction have been determined. Thus, the drainage network and area caused by the precipitation on each sub-basin has been obtained and given in Figure 2(b). Furthermore, main stream for each sub-basin have also been determined in the study.

In this study, important data such as the number of the main streams and secondary streams in each lower basin, total stream lengths, slope of each stream were obtained. The longitudinal sections of main streams have been removed. The total area of the Porsuk Basin is $11,113.66 \mathrm{~km}^{2}$ from the hydrological point of view.

\subsection{Spatial Features of the Porsuk Basin}

Using the digital elevation model of the Porsuk basin, spatial features related to the basin have been derived by obtaining more data and maps of the basin height, slope, view, shaded relief map and so on. Each dataset is an important piece of information in basin planning. The spatial properties of the basin are classified and given in Figures 3(a)-(d).

When the topographic maps of Porsuk basin are examined, it is observed that the basin has elevations ranging between $500 \mathrm{~m}$ and $2250 \mathrm{~m}$ elevations. $50 \%$ of 


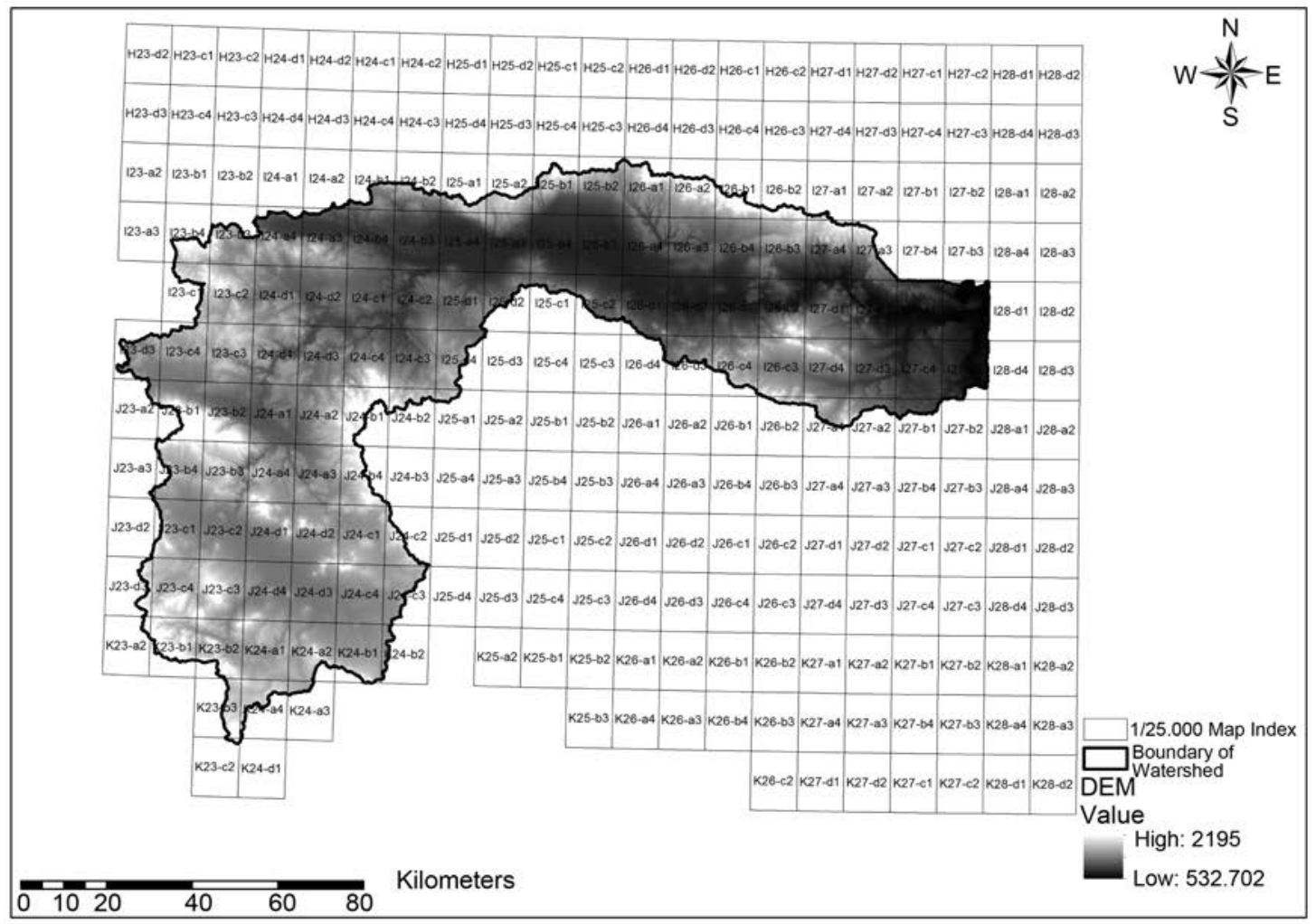

(a)

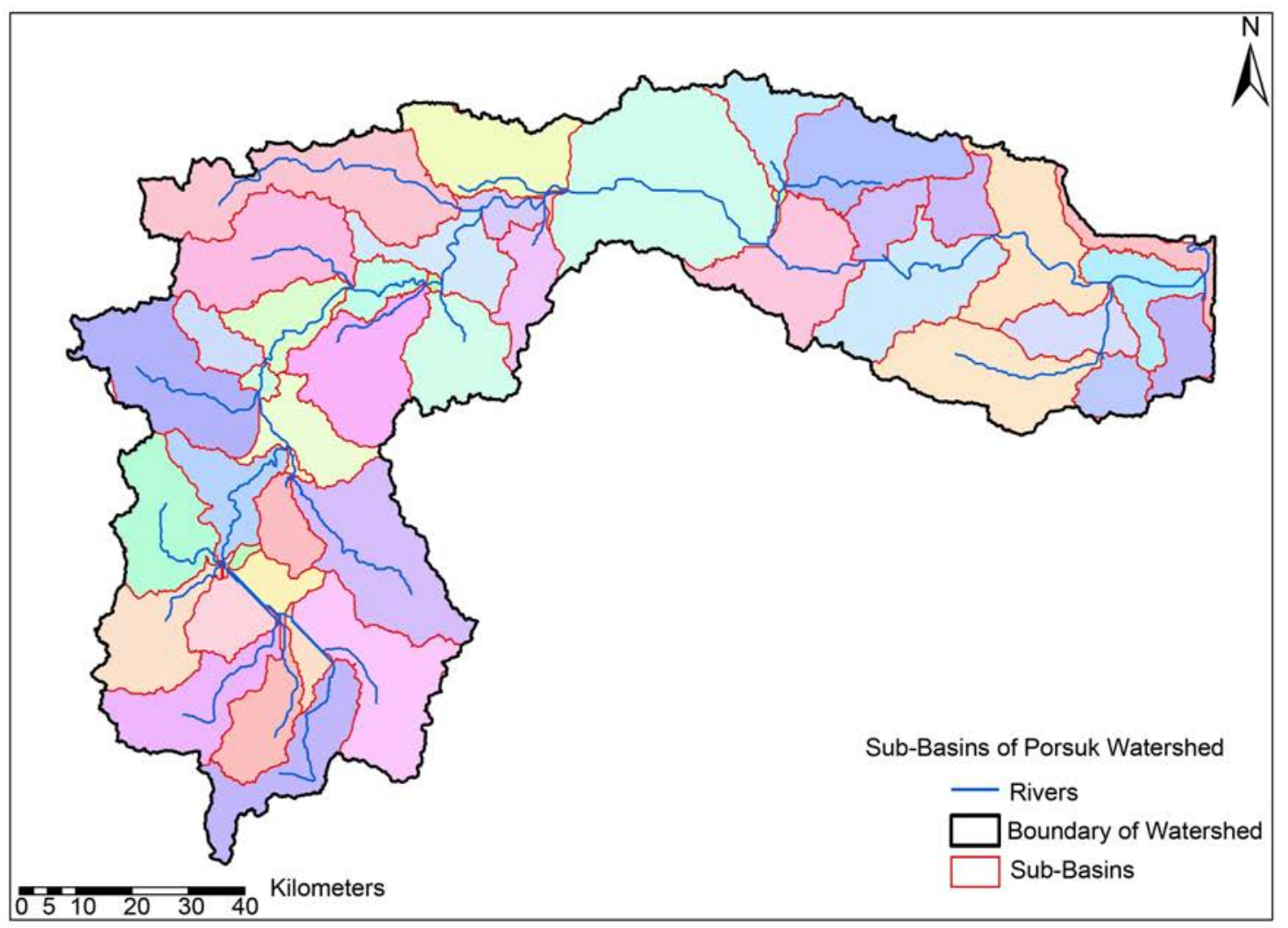

(b)

Figure 2. Drainage network of DEM and lower basins of Porsuk basin. 


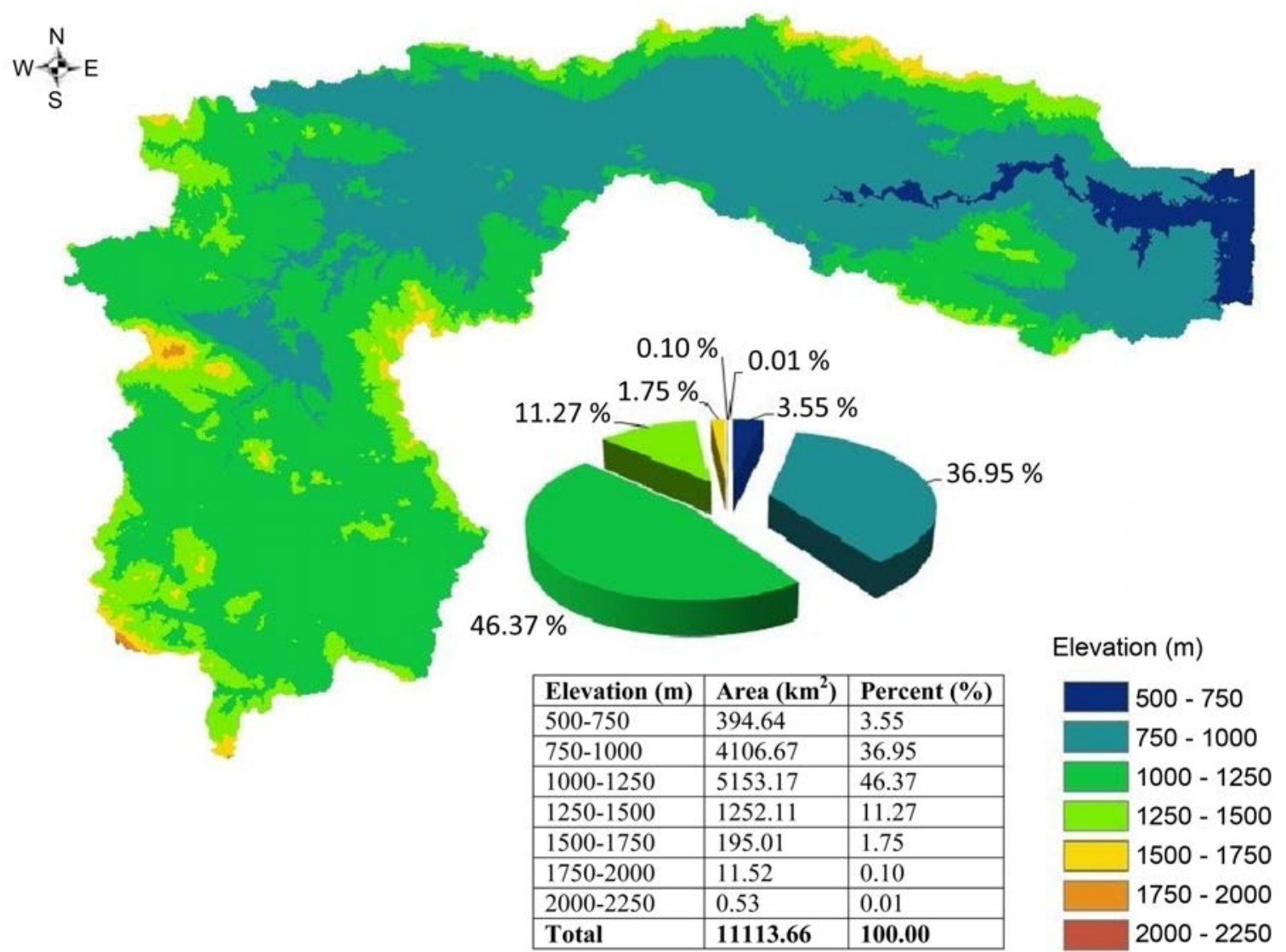

(a)

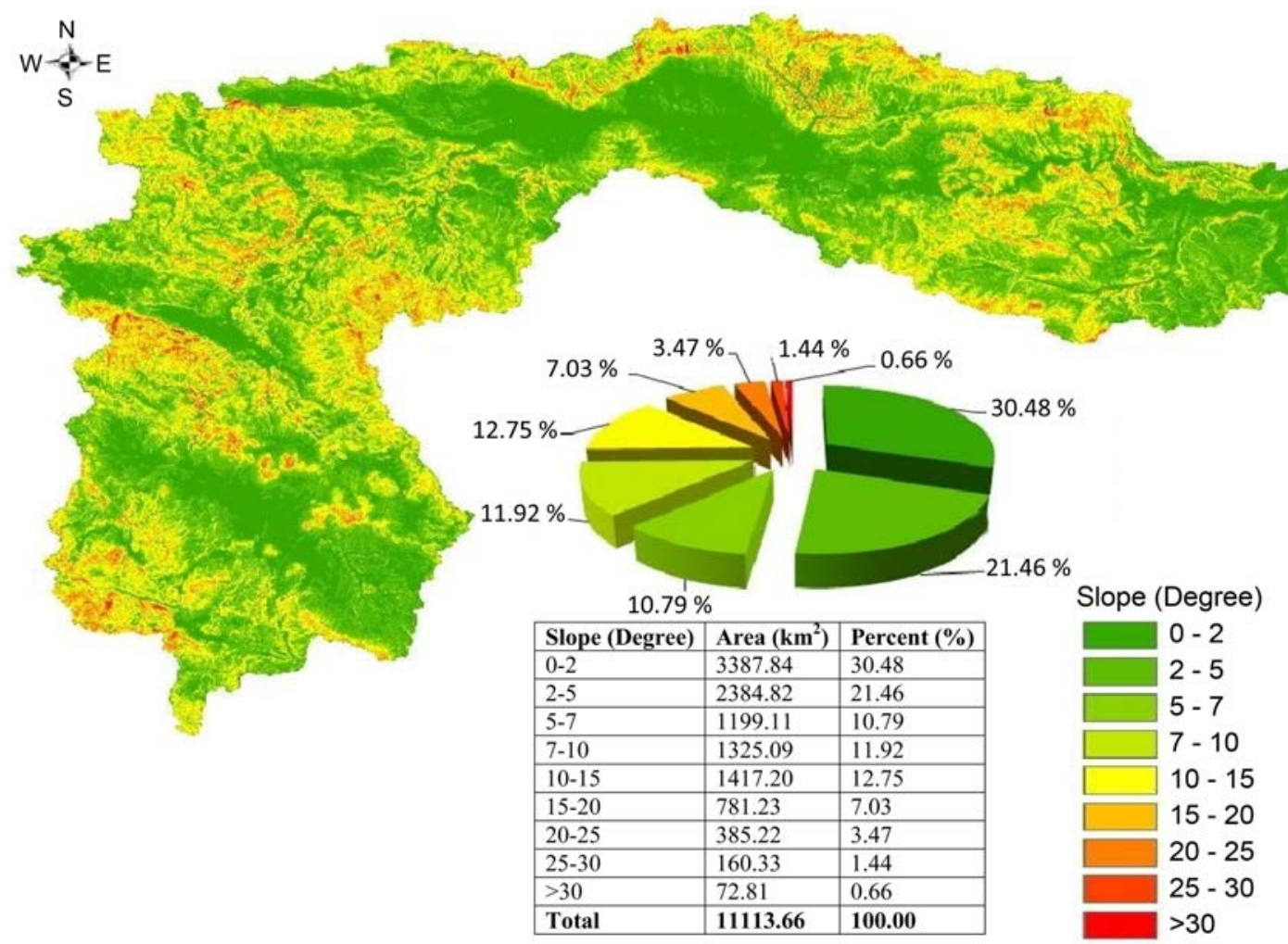

(b) 


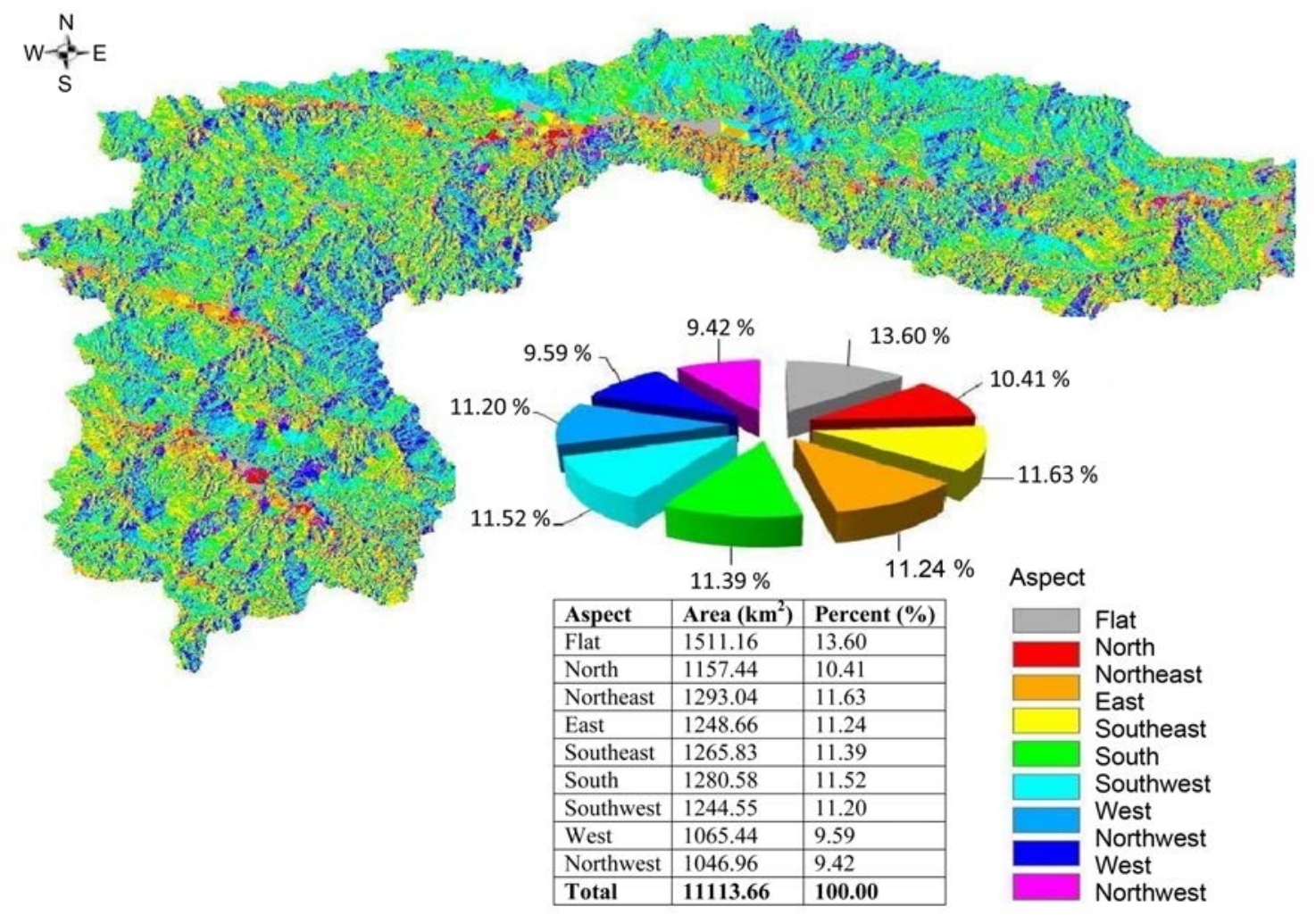

(c)

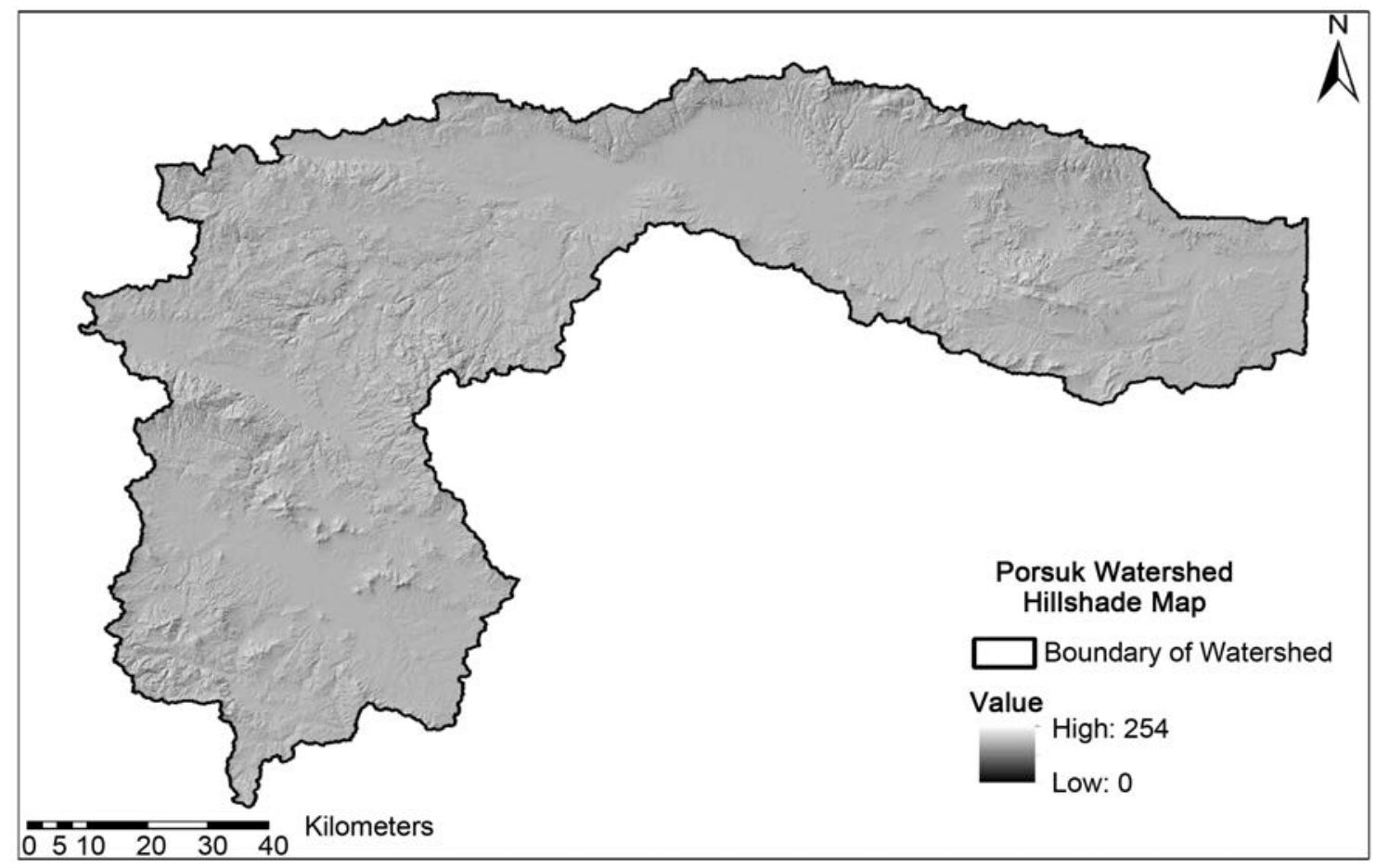

(d)

Figure 3. Spatial maps of Porsuk basin. (a) Elevation (topography) map. (b) Slope map. (c) Aspect map. (d) Shaded map.

the Porsuk basin is more than $1200 \mathrm{~m}$ in height (Figure 3(a)). The basin gener- 
ally has a lower gradient than the 15 degree slope. The slope of the area of approximately $72.81 \mathrm{~km}^{2}$, which is $0.66 \%$ of the Porsuk basin, and it has a topography above $30^{\circ}$ (Figure $3(\mathrm{~b})$ ). Aspect analysis is the geographical angle of the surface to the north. Approximately $3790.96 \mathrm{~km}^{2}$ of the survey area is the slopes facing south, southeast and southwest (Figure $3(\mathrm{c})$ ). From the shaded relief map given in Figure 3(d), it is generally possible to see clearly the structure and flat areas of the basin.

\section{Determination of Meteorological Features of the Basin}

The Porsuk basin reflects the regional climatic characteristics of the Central Anatolian Region. However, it is also under the minor influence of the Aegean region. There are climatic differences between the western and eastern parts of the basin. In general, the summers of the Porsuk basin are arid and hot, and the winters are cold and rainy. The meteorological data in the basin is measured by Meteorological Observation Stations (MOS) located in the provinces of Eskişehir, Kütahya, Afyon, Bilecik, Sakarya and Ankara. Data such as measured rainfall $(\mathrm{mm})$, temperature $\left({ }^{\circ} \mathrm{C}\right)$ and evaporation $(\mathrm{mm})$ of the basin are obtained from the DMI between 1930-2010 (70 years) [5]. These raw data were edited to obtain averages of the monthly average, minimum and maximum values.

\section{Statistical Evaluation of Meteorological Data}

The distribution parameters of the data sets were statistically examined before estimating the distance by using the data obtained from the DMI and DSI and by using the distance-based estimation methods. The data set should show normal distribution, so that a reliable estimation can be made. Estimates made with non-normal data sets will not yield reliable results. For this reason, the distribution parameters of precipitation, temperature and evaporation data sets are evaluated statistically. This assessment is shown in Table 1.

Table 1. Distribution parameters of meteorological data.

\begin{tabular}{cccc}
\hline PARAMETERS & EVAPORATION $(\mathrm{mm})$ & TEMPERATURE $\left({ }^{\circ} \mathrm{C}\right)$ & PRECIPITATION $(\mathrm{mm})$ \\
\hline $\begin{array}{c}\text { Number of } \\
\text { Stations }\end{array}$ & 42 & 86 & 137 \\
$\begin{array}{c}\text { Standard } \\
\text { Deviation }\end{array}$ & 337.93 & 1.4475 & 164.09 \\
Min & 21.2 & 7.1889 & 284.72 \\
Max & 2298.4 & 14.225 & 1249.6 \\
Mean & 1166.7 & 11.223 & 486.19 \\
Median & 1165.5 & 11.179 & 440.05 \\
Skewness & 0.0011155 & -0.068171 & 2.1913 \\
Coefficient & & & 8.4775 \\
Kurtosis & 6.9031 & 2.9384 & \\
Coefficient & & & \\
\hline
\end{tabular}


When the distribution parameters shown in Table 1 are examined, it is seen that the data are not statistically normal distributions. For a normal distribution of a data set, the Skewness coefficients should be close to zero (0), and the Kurtosis coefficients should be close to three (3). In addition, the mean and median values should be close to each other. Some transformations such as $\log , \ln$, sin, cos, tan, and square root were applied to normalize the precipitation, temperature, and evaporation data sets which didn't have normal distribution (Figure 4). These values are used in the estimation process based on the transformations that approximate the normal distribution. Ln for evaporation, log for precipitation transformations have been observed to approach normal distributions. However, since the temperature data show normal distribution without the necessity of these conversions, the distribution is made using the original data. This assessment is shown in Table 2.

When Table 1 and Table 2 are examined, it is observed that the Skewness coefficient approaches zero (0) and the Kurtosis coefficient approximates (3) times of its original value. It is not possible to obtain a perfectly normal distribution, because the data do not have a uniformly distribution and because there are

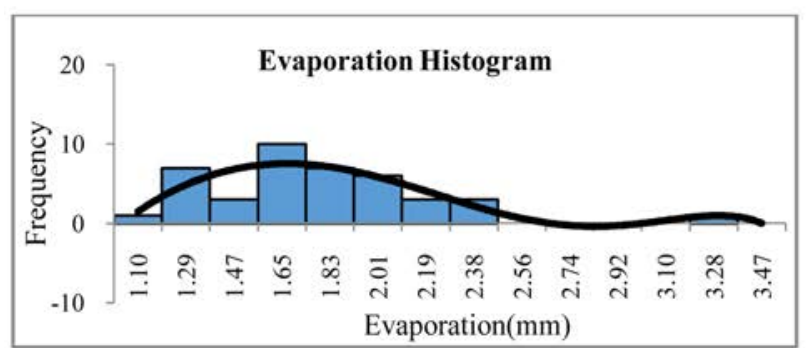

(a)

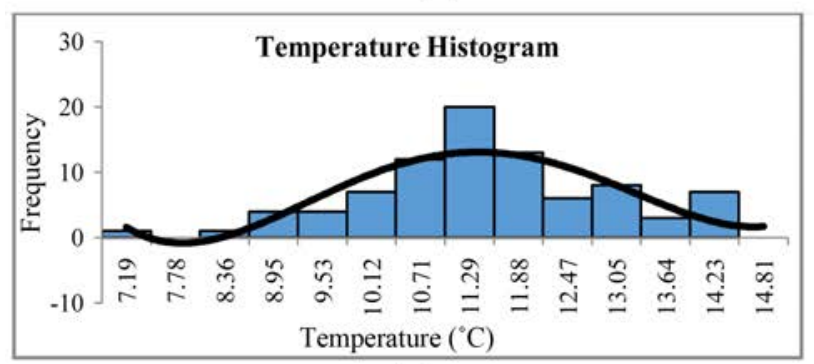

(c)

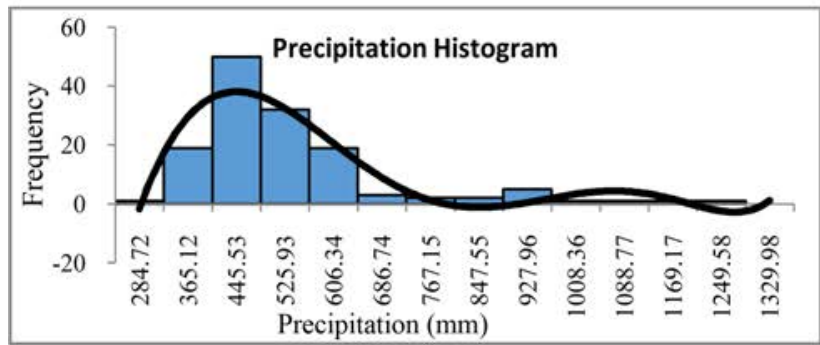

(e)

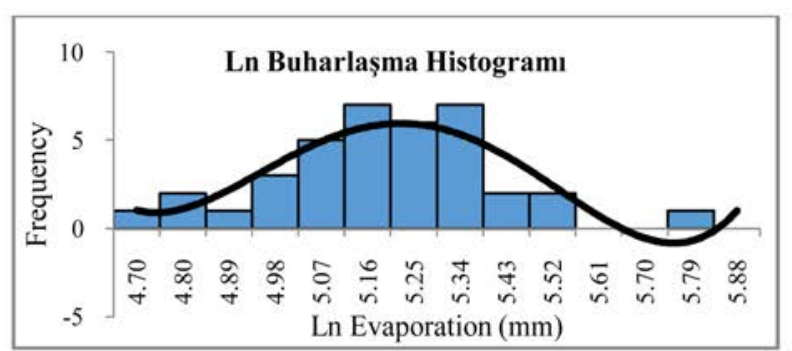

(b)

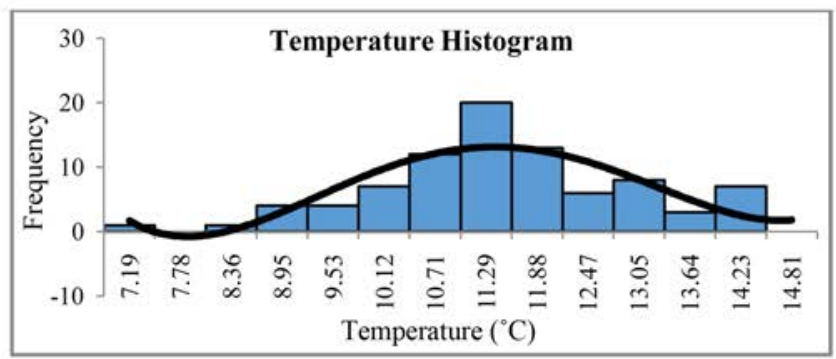

(d)

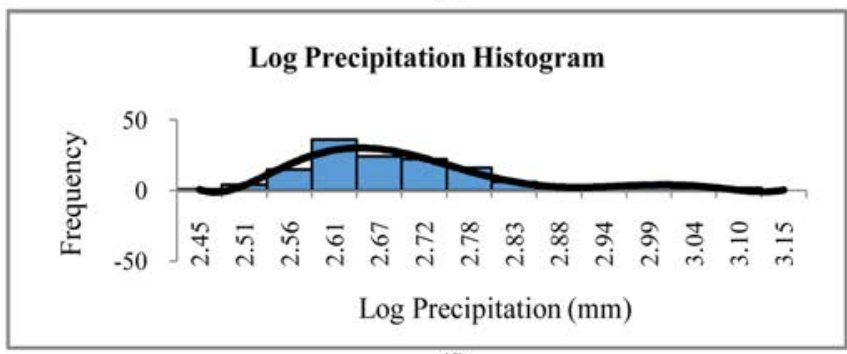

(f)

Figure 4. Crude and regulated histograms of meteorological data of Porsuk basin. (a) Annual evaporation histogram. (b) Annual evaporation histogram converted to ln. (c) Annual temperature histogram. (d) Unconverted annual temperature histogram. (e) Annual precipitation histogram. (f) Log-transformed annual precipitation histogram. 
Table 2. Distribution parameters approaching the normal distribution after statistical analysis of data.

\begin{tabular}{cccc}
\hline PARAMETERS & $\begin{array}{c}\text { LN EVAPORATION } \\
(\mathrm{mm})\end{array}$ & $\begin{array}{c}\text { TEMPERATURE } \\
\left({ }^{\circ} \mathrm{C}\right)\end{array}$ & $\begin{array}{c}\text { LOG PRECIPITATION } \\
(\mathrm{mm})\end{array}$ \\
\hline $\begin{array}{c}\text { Number of } \\
\text { Stations }\end{array}$ & 41 & 86 & 137 \\
$\begin{array}{c}\text { Standard } \\
\text { Deviation }\end{array}$ & 0.23604 & 1.4475 & 0.12037 \\
Min & 4.7046 & 7.1889 & 2.4544 \\
Max & 5.7941 & 14.225 & 3.0968 \\
Mean & 5.1021 & 11.223 & 2.6682 \\
Median & 5.0896 & 11.179 & 2.6435 \\
Skewness & & & 1.2504 \\
Coefficient & 0.27394 & -0.068171 & \\
Kurtosis & & & 4.6878 \\
Coefficient & 3.3119 & 2.9384 & \\
\hline
\end{tabular}

only a few point measurement stations. The closest distribution parameters to normal distributions are obtained by the appropriate transformations.

\section{Positional Prediction Methods}

Estimation is defined as a mathematical method developed to calculate missing data on a series [6]. Estimation, which allows the derivation of new data by means of calculations based on the data at specific points, is actually the computation period of the function necessary for this calculation [7] [8]. Today, in GIS applications, spatial coordinates are calculated from known points, that is to say point-referenced, and distance-dependent spatial estimation methods are used to represent the field in terms of space. As a result of estimation, raster surfaces are calculated from vector data defined on point geometries. Spanning and distance-dependent estimation methods (IDW, Natural Neighbors, Spline, Kriging, etc.) try to estimate the value at unknown points. Based on the modeled data model, selected estimation methods reveal more accurate models. In this study, the applicability of the IDW and Ordinary Kriging methods to the data is investigated and the raster surfaces are cut to the basin boundary (clip) to model rainfall, temperature and evaporation distribution maps for the basin.

\subsection{Inverse Distance Weighted Method-IDW}

Inverse distance weighted method is a method of estimation that takes a higher weight value than nearby points and considers all possible sample points. Each sample point has a weight value in the opposite direction according to its distance to the point to be estimated. $x_{0}$ predicted value is calculated as shown in Equation (3) 


$$
\begin{gathered}
W_{i}=\frac{\frac{1}{d_{i}^{p}\left(x_{i}\right)}}{\sum_{i=1}^{n} \frac{1}{d_{i}^{p}\left(x_{i}\right)}} \\
Z^{*}\left(x_{0}\right)=\sum W_{i} \cdot Z\left(x_{i}\right)
\end{gathered}
$$

where:

$Z^{*}\left(x_{0}\right)$ : Value of the estimate at point $x_{0}$,

$Z\left(x_{i}\right)$ : sample point value at $x_{p}$

$W_{i}$ : The inverse distance weight according to the point $x_{0}$ at the point $x_{i}$,

$d$ : the distance between the sample point and the point to be estimated,

$p$ : exponential value,

$n$ : number of sample points.

\subsection{Ordinary Kriging Method}

The Kriging interpolation method is an interpolation method that estimates optimal values of the data at other points by using known values at near locations [9]. Kriging interpolation is a technique in which the unbiased estimation of the positional changes at the sampled points using semi-parametric structural features is performed optimally [10] [11]. The most important feature that distinguishes the Kriging method from other methods is that a variance value can be calculated for each estimated point or area, which is a measure of the confidence level of the value [11]. Ordinary Kriging is the simplest form of kriging. It uses dimensionless points to estimate other dimensionless points, e.g. elevation contour plots. In Ordinary kriging, the regionalized variable is assumed to be stationary.

In our case $Z$, at point $p, Z_{e}(p)$ to be calculated using a weighted average of the known values or control points (Equation (3)):

$$
z_{e}(p)=\sum w_{i} \cdot z\left(p_{i}\right)
$$

This estimated value will most likely differ from the actual value at point $p$, $Z_{a}(p)$, and this difference is called the estimation error (Equation (4))

$$
\varepsilon_{p}=z_{e}(p)-z_{a}(p)
$$

If no drift exists and the weights used in the estimation sum to one, then the estimated value is said to be unbiased. The scatter of the estimates about the true value is termed the error or estimation variance (Equation (5)),

$$
\sigma_{z}^{2}=\frac{\sum_{i=1}^{n}\left[z_{e}\left(p_{i}\right)-z_{a}\left(p_{i}\right)\right]_{i}^{2}}{n}
$$

Kriging tries to choose the optimal weights that produce the minimum estimation error. Optimal weights, those that produce unbiased estimate sand have a minimum estimation variance, are obtained by solving a set of simultaneous equations (Equations (6) and (7)). 


$$
\begin{gathered}
w_{1} \gamma\left(h_{11}\right)+w_{2} \gamma\left(h_{12}\right)+w_{3} \gamma\left(h_{13}\right)=\gamma\left(h_{1 p}\right) \\
w_{1} \gamma\left(h_{21}\right)+w_{2} \gamma\left(h_{22}\right)+w_{3} \gamma\left(h_{23}\right)=\gamma\left(h_{2 p}\right) \\
w_{1} \gamma\left(h_{31}\right)+w_{2} \gamma\left(h_{32}\right)+w_{3} \gamma\left(h_{33}\right)=\gamma\left(h_{3 p}\right) \\
w_{1}+w_{2}+w_{3}=1
\end{gathered}
$$

A fourth variable is introduced called the Lagrange multiplier (Equation (8)),

$$
\left[\begin{array}{cccc}
\gamma\left(h_{11}\right) & \gamma\left(h_{12}\right) & \gamma\left(h_{13}\right) & 1 \\
\gamma\left(h_{21}\right) & \gamma\left(h_{21}\right) & \gamma\left(h_{23}\right) & 1 \\
\gamma\left(h_{31}\right) & \gamma\left(h_{32}\right) & \gamma\left(h_{33}\right) & 1 \\
1 & 1 & 1 & 0
\end{array}\right] \cdot\left[\begin{array}{c}
w_{1} \\
w_{2} \\
w_{3} \\
\lambda
\end{array}\right]=\left[\begin{array}{c}
\gamma\left(h_{1 p}\right) \\
\gamma\left(h_{2 p}\right) \\
\gamma\left(h_{3 p}\right) \\
1
\end{array}\right]
$$

Once the individual weights are known, an estimation can be made by Equation (9),

$$
z_{e}(p)=w_{1} z_{1}+w_{2} z_{2}+w_{3} z_{3}
$$

And an estimation variance can be calculated by Equation (10),

$$
\sigma_{z}^{2}=w_{1} \gamma\left(h_{1 p}\right)+w_{2} \gamma\left(h_{21 p}\right)+w_{13} \gamma\left(h_{3 p}\right)+\lambda
$$

\section{Modeling of Meteorological Data Based on Seydisuyu Basin Distribution Maps}

\subsection{Modeling of Meteorological Data on the Basin Using Inverse Distance Weighted Method}

The geographical locations of meteorological data (precipitation, temperature, evaporation) are shown in Figures 5(a)-(c). The raw data given in Figure 4 were transformed into normal distribution values in order to normalize the data, since it was not statistically normal. The histograms of the transformed data were generated and statistically re-evaluated. The distribution maps on the basin are then modeled using the distance tiller weighting method. The modeling results are given in Figures 6(a)-(c).

The maps obtained as a result of the estimation should be converted to their actual values since the converted applied result is obtained. For this reason, values are converted to real meteorological values using the raster calculator in precipitation and evaporation data. The data for the temperature distribution are not recycled, because they are modeled with their original values (Figures $7(\mathrm{a})-(\mathrm{c}))$.

\section{Accuracy Analysis of IDW Method}

Randomly selected meteorological observation stations with appropriate spatial distribution were selected as control points and rainfall, temperature, evaporation distributions were applied by IDW interpolation method (without these data to determine the correctness of the predictions). These control stations are selected up to $20 \%$ of the number of stations available. This number is ideal for estimating the accuracy of the distribution. Then, we compare the calculated values 


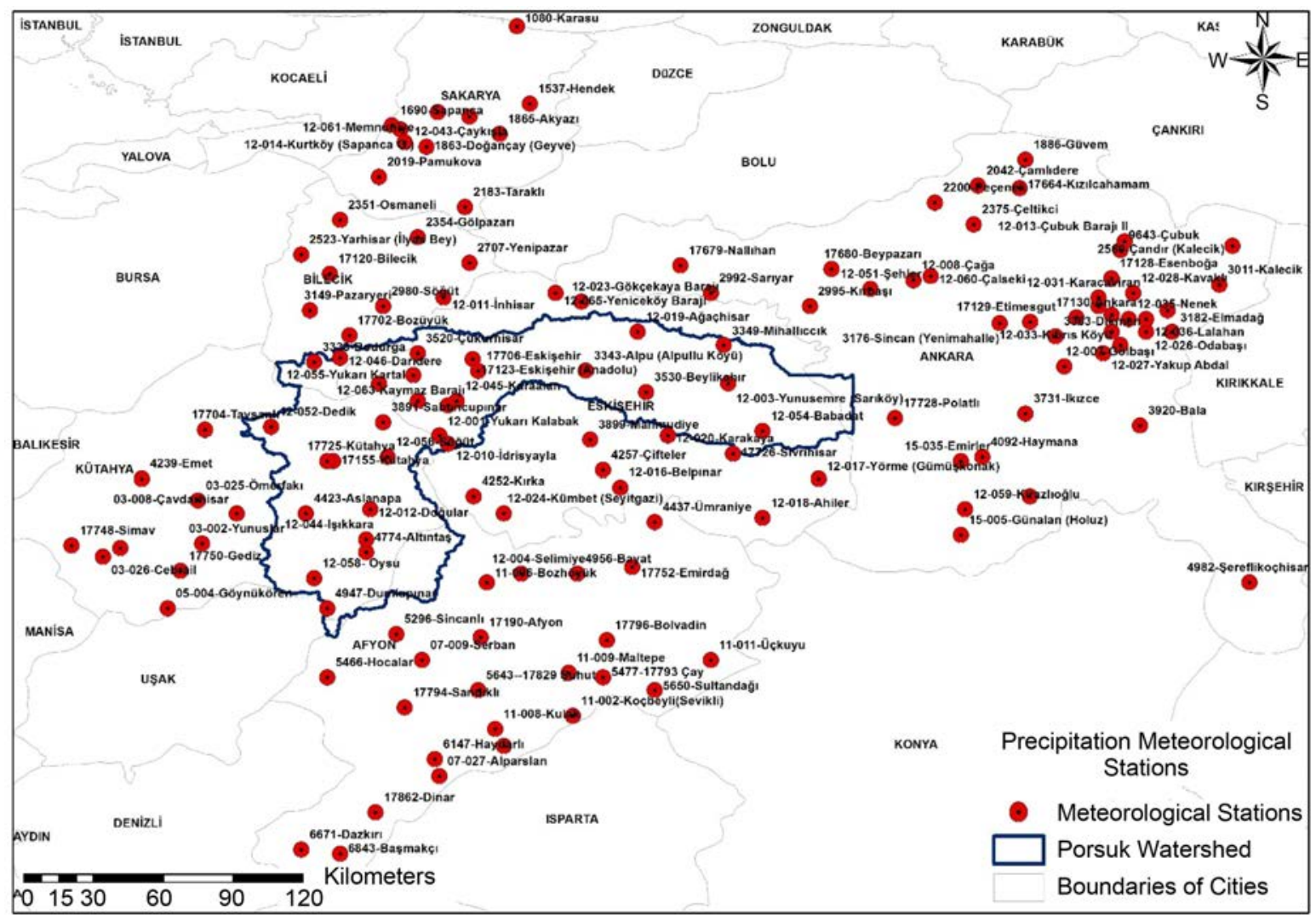

(a)

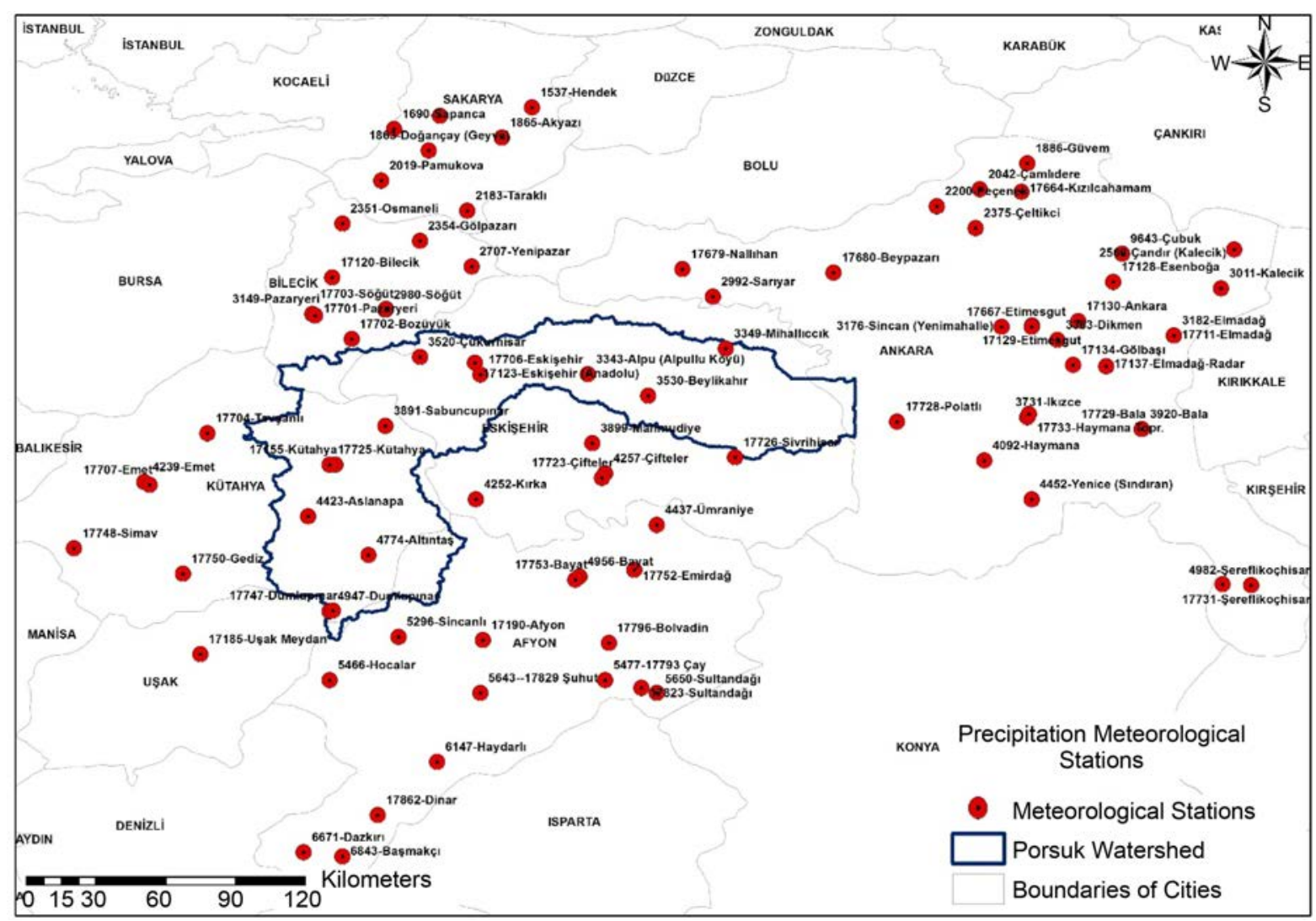

(b) 


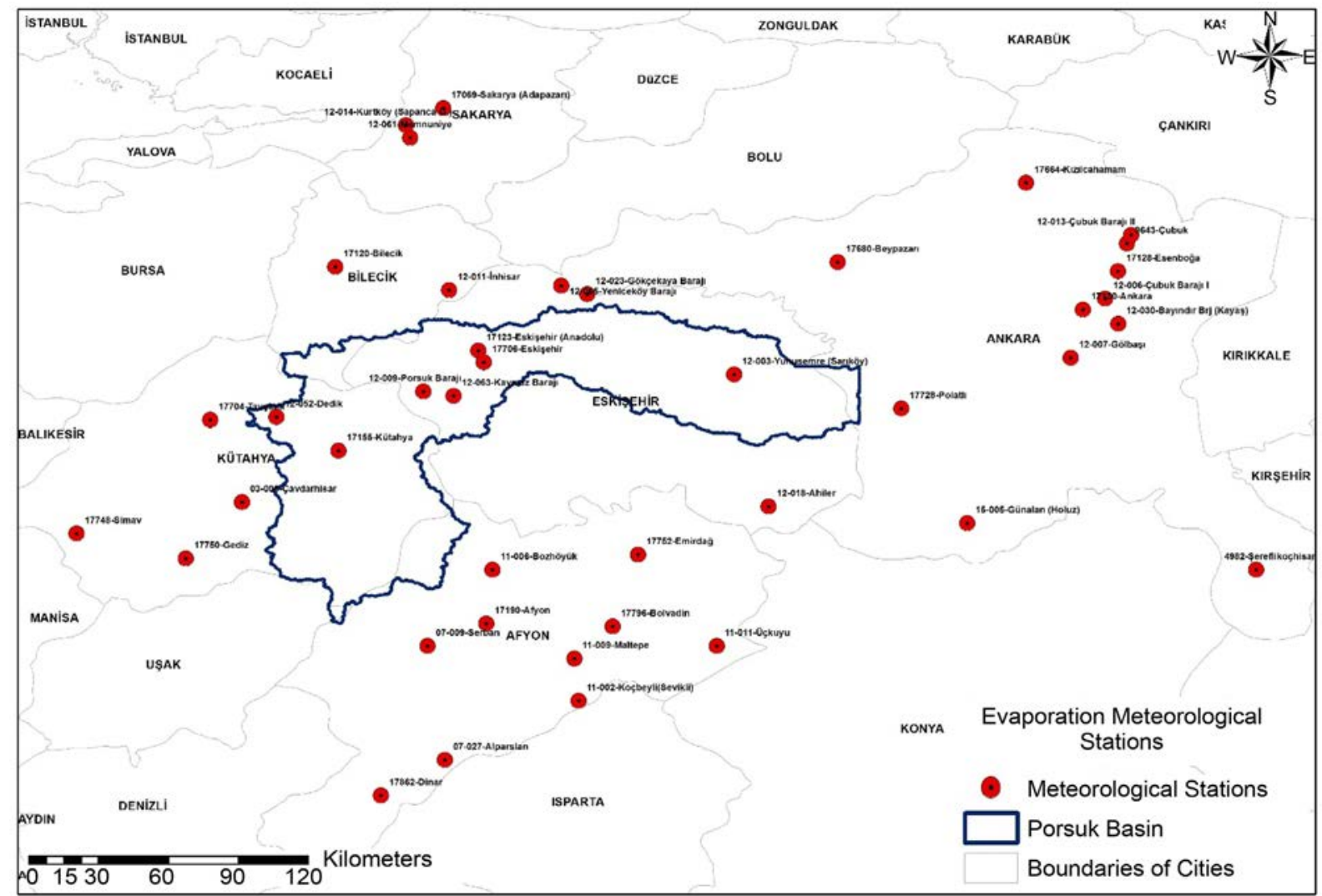

(c)

Figure 5. Spatial maps of meteorological stations. (a) Precipitation Measurement Stations. (b) Temperature Measurement Stations. (c) Evaporation measurement stations.

with the surface values calculated by using the data that were transformed for the normal distribution before the actual values of the control stations, and the accuracy of the estimations made by calculating the squared mean errors (SME) were analyzed (Tables 3-5).

\subsection{Modeling of Meteorological Data on Basin Using Ordinary Kriging Method}

Ordinary Kriging method was chosen as the second method for distribution of spot meteorological data in the area of the Porsuk basin. Kriging methods require a more comprehensive statistical evaluation as compared to the IDW method. In order to create the Kriging model, first the variogram models of the data must be created. The variance of the difference between the values of the spatial variables in geo-statistics is expressed by the variogram function (Figure 8). The variogram function is expressed as the variance of the difference between two positional variables at distance $s$ and is denoted by $2 \gamma(s)$. The semi-variogram function is calculated as in the Equation (12), which is expressed as half of the variogram function [12] [13] [14] [15].

$$
\gamma(s)=\frac{1}{2 n(s)} \sum_{S_{i j}}^{n(s)} N\left(x_{i} y_{i}\right)-N\left(x_{j}, y_{j}\right)^{2}
$$




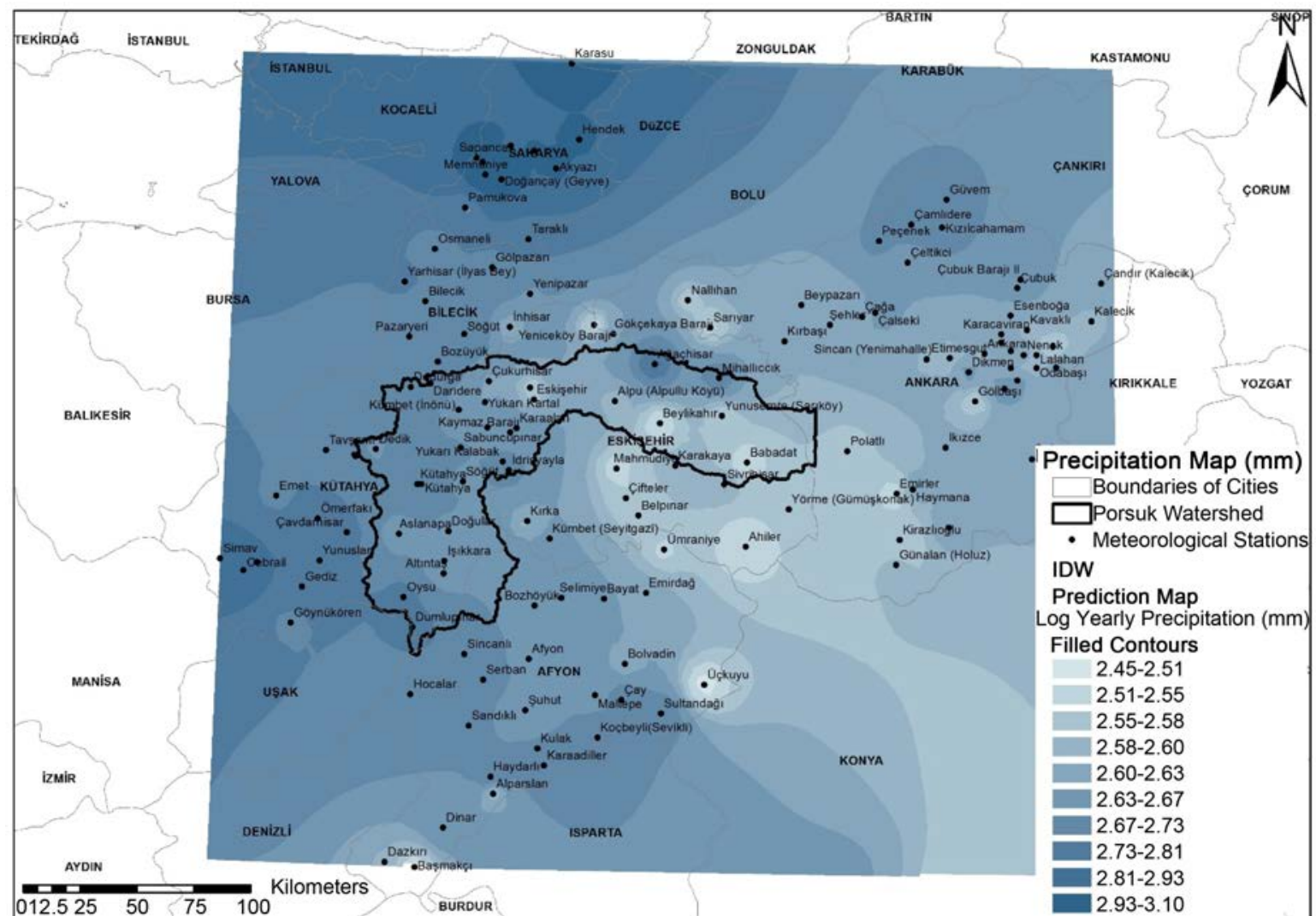

(a)

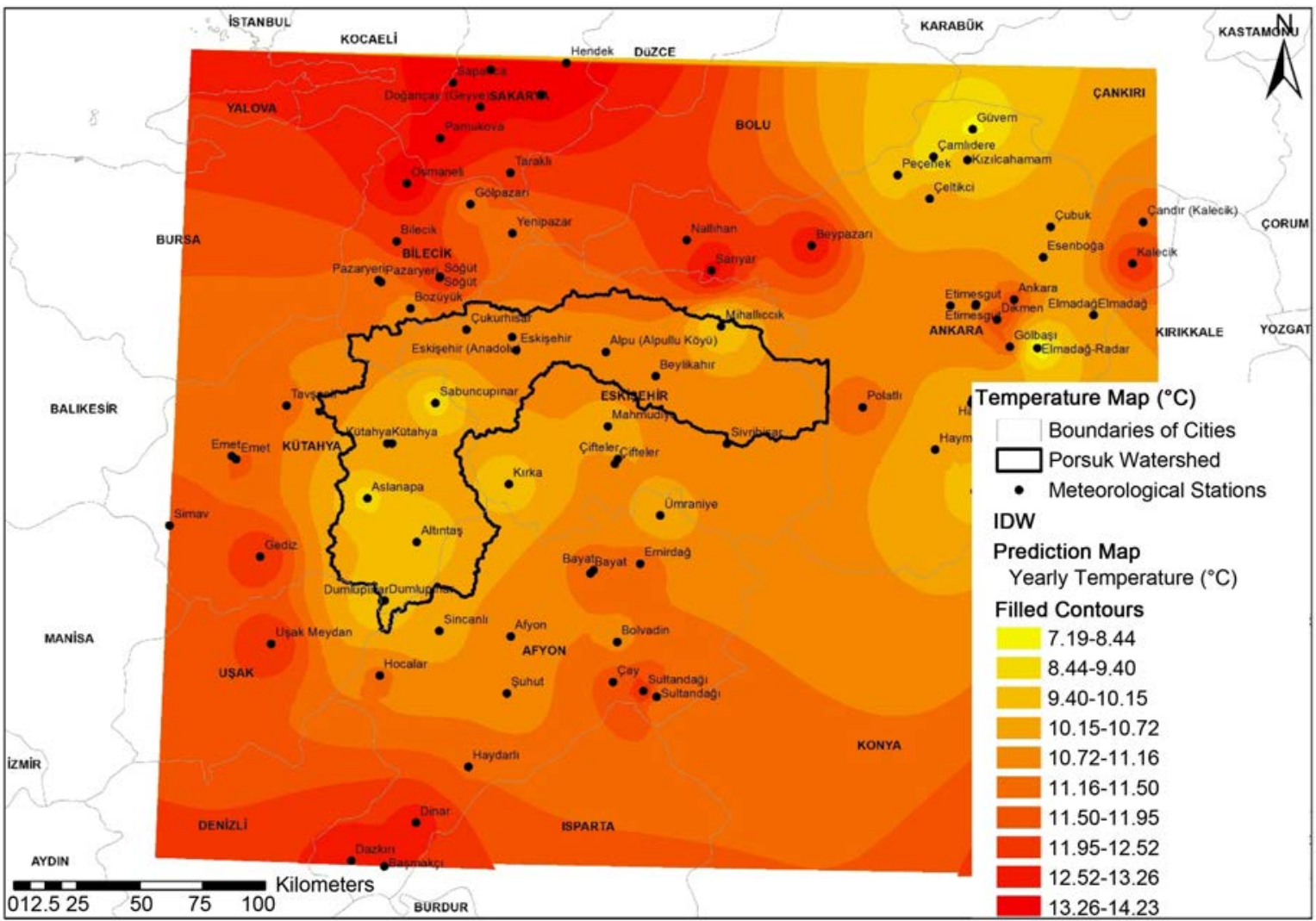

(b) 


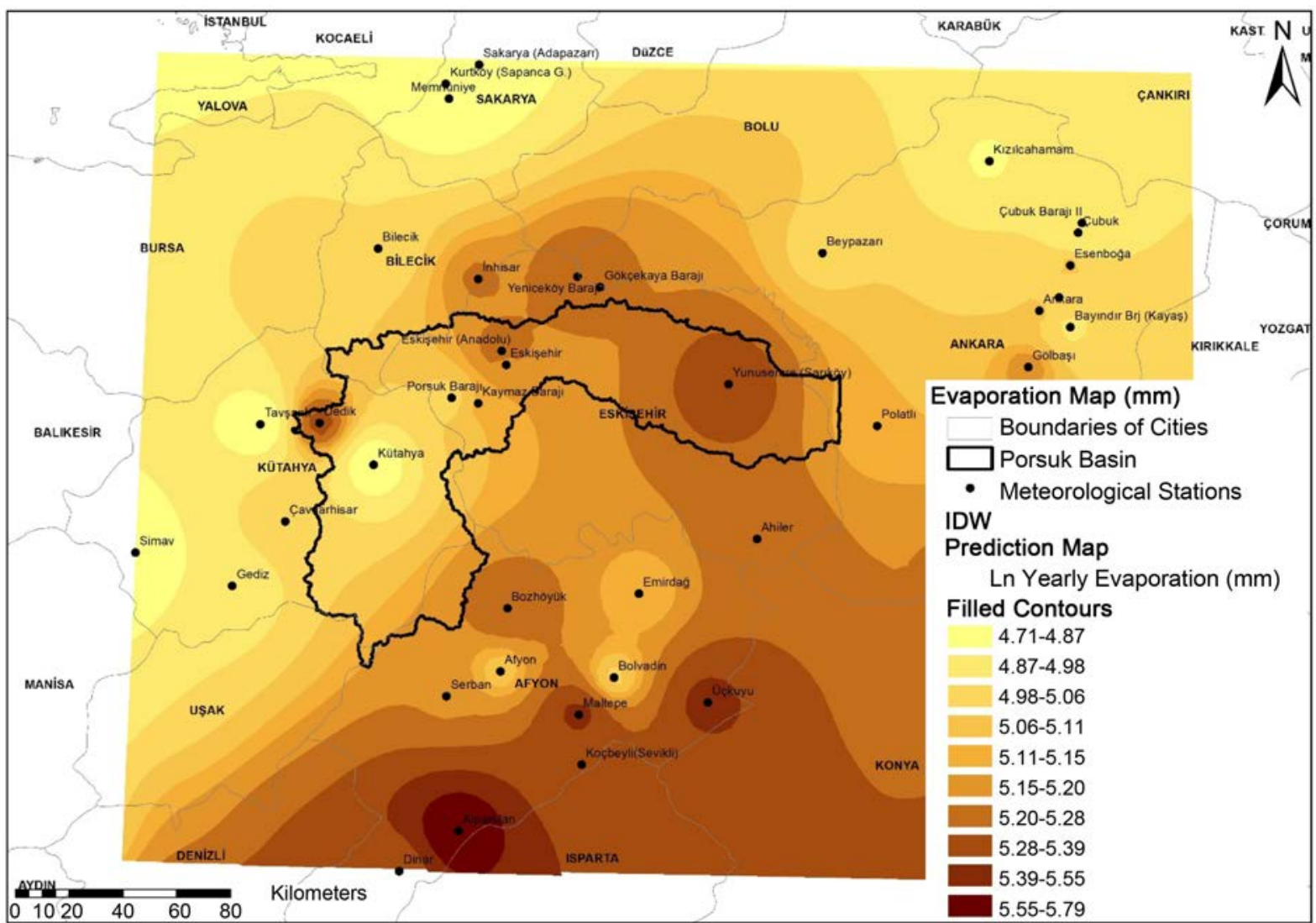

(c)

Figure 6. (a)-(c) Distribution model of data by IDW method. (a) Log precipitation distribution by IDW method. (b) Temperature distribution with IDW Method. (c) ln evaporation distribution with IDW method.

$$
S_{i j}=\sqrt{\left(x_{i}-x_{j}\right)^{2}+\left(y_{i}-y_{j}\right)^{2}}
$$

$S_{i j}=$ Horizontal distance between $i$ and $j$ points.

$n(s)=$ Number of point pairs at distance $s$;

$N_{i}=$ Geodesic undulation in point I;

$N_{j}=$ Geodesic undulation in point I;

$\mathrm{\gamma}(s)=\mathrm{S}$ semiparametric value;

The necessary rules to be taken into account when calculating the semi-variogram are [16] [17]:

1) There must be enough sample pairs for the distance between the samples to be used in the calculations.

2) Since there cannot be enough sample pairs in the hand, it is necessary to calculate the variance diagram for the half of the longest edge of the land.

3) In cases where irregular sampling is performed, it is necessary to take the smallest sample interval as an initial value when calculating.

Theoretically, when $s=0$, the value of the variogram is equal to zero $\left[\mathrm{\gamma}_{(0)}=0\right]$. There is a limit value that can be determined from the distance dependent change, which is the distance between the two closest samples. In practice, the 


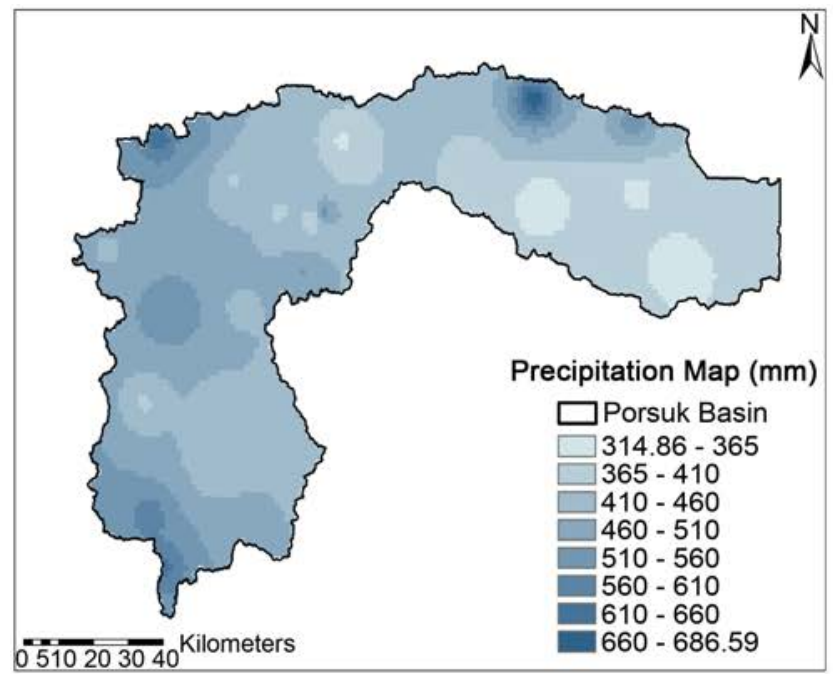

(a)

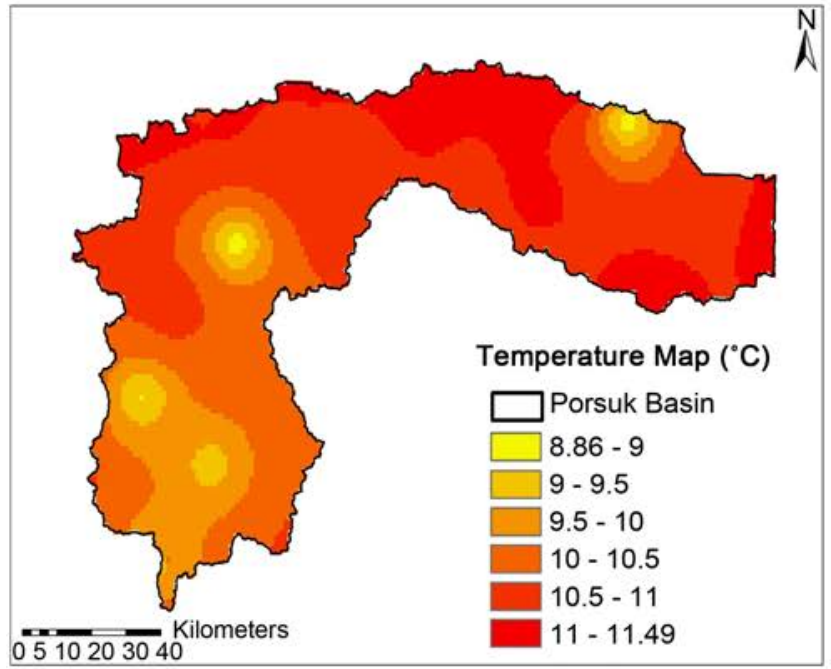

(b)

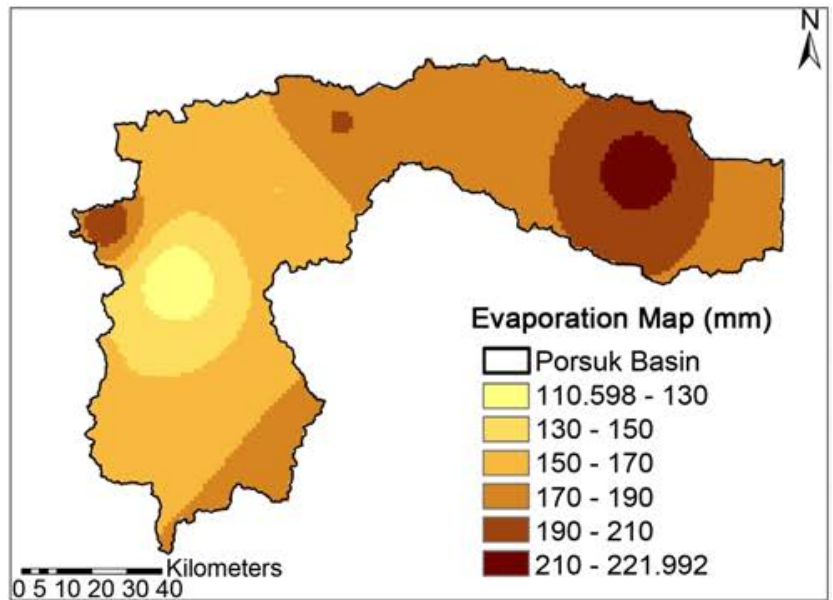

(c)

Figure 7. (a)-(c) Rainfall, temperature and evaporation distribution maps prepared by applying IDW method of Porsuk Basin. (a) Precipitation map. (b) Temperature map. (c) Evaporation map. 
Table 3. Real and calculated values of rainfall control stations.

\begin{tabular}{|c|c|c|c|}
\hline \multirow{2}{*}{ STATION NAME } & \multirow{2}{*}{$\begin{array}{c}\text { MEASURED LOG } \\
\text { PRECIPITATION VALUE } \\
(\mathrm{mm})\end{array}$} & \multirow{2}{*}{$\begin{array}{c}\text { CALCULATED } \\
\text { VALUE } \\
\text { IDW }\end{array}$} & \multirow{2}{*}{ ERROR } \\
\hline & & & \\
\hline 4437-Ümraniye & 2.533454 & 2.608392 & 0.074938045 \\
\hline 5466-Hocalar & 2.661311 & 2.703292 & 0.041980734 \\
\hline 6671-Dazkırı & 2.598275 & 2.677013 & 0.078738536 \\
\hline 6843-Başmakçı & 2.521119 & 2.673091 & 0.151971227 \\
\hline 11-011-Üçkuyu & 2.482522 & 2.661763 & 0.179241043 \\
\hline 2992-Sariyar & 2.532435 & 2.638344 & 0.105908302 \\
\hline 3920-Bala & 2.627451 & 2.606468 & -0.020983356 \\
\hline 12-008-Çağa & 2.585554 & 2.612541 & 0.026987383 \\
\hline 12-034-Karapürçekli & 2.645376 & 2.61098 & -0.034396082 \\
\hline 12-060-Çalseki & 2.676402 & 2.618173 & -0.058229379 \\
\hline 2354-Gölpazarı & 2.686786 & 2.741485 & 0.054698918 \\
\hline 2707-Yenipazar & 2.659831 & 2.691772 & 0.031940775 \\
\hline 3530-Beylikahır & 2.49799 & 2.636779 & 0.138789285 \\
\hline 3899-Mahmudiye & 2.515543 & 2.629744 & 0.11420091 \\
\hline 4257-Çifteler & 2.543572 & 2.595262 & 0.051690002 \\
\hline 17706-Eskişehir & 2.570368 & 2.601006 & 0.030638474 \\
\hline 17726-Sivrihisar & 2.607603 & 2.561625 & -0.045977767 \\
\hline $\begin{array}{l}\text { 12-017-Yörme } \\
\text { (Gümüşkonak) }\end{array}$ & 2.584371 & 2.563882 & -0.020488916 \\
\hline 12-020-Karakaya & 2.592123 & 2.608154 & 0.016031167 \\
\hline 12-055-Yukarı Kartal & 2.622784 & 2.647065 & 0.024281706 \\
\hline 12-063-Kaymaz Baraj1 & 2.559511 & 2.704239 & 0.144728439 \\
\hline 4423-Aslanapa & 2.602326 & 2.704016 & 0.101689901 \\
\hline 03-026-Cebrail & 2.93984 & 2.825682 & -0.114158209 \\
\hline 05-004-Göynükören & 2.69653 & 2.7665 & 0.069970305 \\
\hline 12-012-Doğular & 2.649215 & 2.671991 & 0.022776043 \\
\hline 12-058-Oysu & 2.767052 & 2.717811 & -0.049241686 \\
\hline \multirow[t]{2}{*}{$\begin{array}{l}\text { 17069-Sakarya } \\
\text { (Adapazarı) }\end{array}$} & 2.916222 & 2.951641 & 0.035419255 \\
\hline & n Square Error (MSE) & & 0.08221 \\
\hline
\end{tabular}

change of the difference between the values cannot be determined at a smaller distance than this distance, which leads to a discontinuity in the origin of the variogram. One reason for discontinuity is sampling and analysis mistakes. In the variogram, this is indicated as "nugget effect" $C_{0}$. This value is also called the uncontrolled variance of effects [15] [18]. It does not affect the estimate value. 
Table 4. Actual and calculated values of temperature measuring control stations.

\begin{tabular}{|c|c|c|c|}
\hline \multirow{2}{*}{ STATION NAME } & \multirow{2}{*}{$\begin{array}{c}\text { MEASURED } \\
\text { TEMPERATURE } \\
\left({ }^{\circ} \mathrm{C}\right)\end{array}$} & $\begin{array}{c}\text { CALCULATED } \\
\text { VALUE }\end{array}$ & \multirow{2}{*}{ ERROR } \\
\hline & & IDW & \\
\hline 4437-Ümraniye & 10.14226 & 10.99191 & 0.849644078 \\
\hline 17185-Uşak Meydan & 12.53458 & 11.02207 & -1.512515026 \\
\hline 1886-Güvem & 8.033796 & 10.24181 & 2.208015733 \\
\hline 2042-Çamlıdere & 8.709537 & 10.29777 & 1.588237307 \\
\hline 3182-Elmadă̆ & 10.11424 & 10.73265 & 0.618415242 \\
\hline 3731-Ikızce & 10.01083 & 10.73928 & 0.728442802 \\
\hline 3920-Bala & 8.958552 & 10.96431 & 2.005753968 \\
\hline 4982-Şereflikoçhisar & 12.4041 & 12.99925 & 0.59514217 \\
\hline 17711-Elmadağ & 10.91806 & 10.73265 & -0.185404203 \\
\hline 2351-Osmaneli & 14.18643 & 12.24579 & -1.940636351 \\
\hline 17701-Pazaryeri & 12.14319 & 10.29287 & -1.850323459 \\
\hline 17702-Bozüyük & 10.64808 & 11.40021 & 0.752125903 \\
\hline 3530-Beylikahır & 11.09236 & 10.86663 & -0.225731364 \\
\hline $\begin{array}{l}\text { 17123-Eskişehir } \\
\text { (Anadolu) }\end{array}$ & 10.75778 & 10.96861 & 0.210831497 \\
\hline 17723-Çifteler & 11.28875 & 10.29495 & -0.993801389 \\
\hline 17155-Kütahya & 10.67912 & 10.57766 & -0.101466833 \\
\hline \multirow[t]{2}{*}{$\begin{array}{l}\text { 1863-Doğançay } \\
\text { (Geyve) }\end{array}$} & 13.6713 & 13.38929 & -0.282005481 \\
\hline & n Square Error (MSE) & & 1.204414 \\
\hline
\end{tabular}

Table 5. Actual and calculated values of evaporation control stations.

\begin{tabular}{|c|c|c|c|}
\hline \multirow{3}{*}{ STATION NAME } & \multirow{3}{*}{$\begin{array}{l}\text { MEASURED LN } \\
\text { EVAPORATION } \\
\text { AMOUNT }(\mathrm{mm})\end{array}$} & $\begin{array}{c}\text { CALCULATED } \\
\text { VALUE }\end{array}$ & \multirow{3}{*}{ ERROR } \\
\hline & & \multirow[b]{2}{*}{ IDW } & \\
\hline & & & \\
\hline 17752-Emirdağ & 5.078269 & 5.22072 & 0.142455099 \\
\hline 17862-Dinar & 5.274596 & 5.21786 & -0.056731492 \\
\hline 07-027-Alparslan & 5.794077 & 5.2377 & -0.556376588 \\
\hline 17680-Beypazarı & 5.021803 & 5.12606 & 0.10425682 \\
\hline $\begin{array}{c}\text { 12-030-Bayındır } \\
\text { Brj (Kayaş) }\end{array}$ & 4.947599 & 5.05591 & 0.108313341 \\
\hline $\begin{array}{l}\text { 17123-Eskişehir } \\
\text { (Anadolu) }\end{array}$ & 5.281088 & 5.15623 & -0.124860661 \\
\hline 17155-Kütahya & 4.704643 & 5.12474 & 0.420093136 \\
\hline 12-061-Memnuniye & 4.73533 & 4.76994 & 0.034609451 \\
\hline & Square Error (MSE) & & 0.261948 \\
\hline
\end{tabular}


Only change in the Kriging variance is caused [14] [19].

The spatial variable variogram stops incrementing after a certain distance, and the peak variance (sill, sill) begins to take values around the value " $C_{0}+C$ ". The distance domain (structural distance, range) where it reaches the threshold value of the variogram is called " $a$ ". For larger distances than this particular distance, the positional dependence comes to an end [11] [14]. The determination of the experimental variogram structure of observational data and the fitting of a theoretical model to this variogram form the basis of geostatistical studies [11] [20] [21] [22]. The most common variogram models used in geostatistics are shown in Table 6. The parameters forming the variogram models are shown in Table 7.

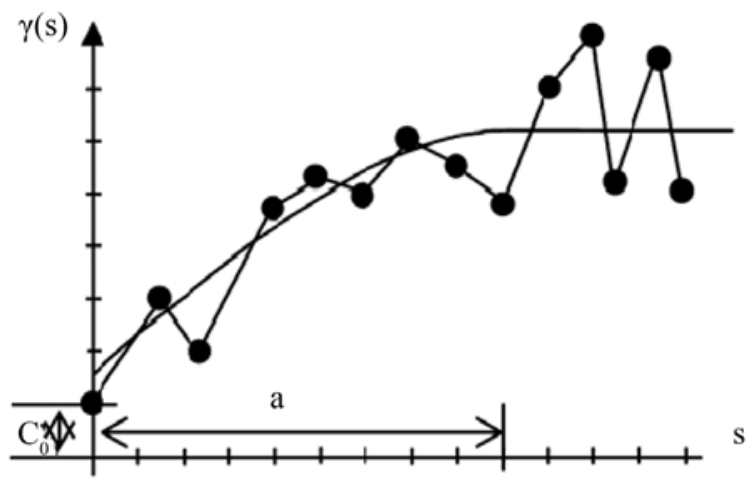

Figure 8. Variogram plot and parameters.

Table 6. Various variogram models [23].

\begin{tabular}{|c|c|c|}
\hline Variogram model & Function & State \\
\hline Gauss & $\gamma(s)=C_{0}+C\left(1-\exp \left(\frac{-S^{2}}{a^{2}}\right)\right)$ & \\
\hline Exponential & $\gamma(s)=C_{0}+C\left(1-\exp \left(\frac{-S}{a}\right)\right)$ & \\
\hline \multirow[t]{2}{*}{ Global } & $\mathrm{\gamma}(s)=C_{0}+C\left(\left(\frac{3 S}{2 a}\right)-\left(\frac{S^{3}}{2 a^{3}}\right)\right)$ & $(0 \leq s \leq a)$ \\
\hline & $\gamma(s)=C_{0}+C$ & $s>a$ \\
\hline Linear & $\gamma(s)=C_{0}+C \cdot S$ & \\
\hline Logarithmic & $\mathrm{\gamma}(s)=C_{0}+C \cdot \log (s)$ & $(s>0)$ \\
\hline
\end{tabular}

Table 7. Variogram parameters.

\begin{tabular}{cccccccc}
\hline & $\begin{array}{c}\text { Active Lag } \\
\text { Distance }\end{array}$ & $\begin{array}{c}\text { Lag Class } \\
\text { Distance } \\
\text { (Uniform } \\
\text { Interval) }\end{array}$ & Isotropy & $\begin{array}{c}\text { Model } \\
\text { Type }\end{array}$ & $\begin{array}{c}\text { Nugget } \\
\text { Variance } \\
\left(C_{0}\right)\end{array}$ & $\begin{array}{c}\text { Sill } \\
\left(C_{0}+C\right)\end{array}$ & Range (A) \\
\hline $\begin{array}{c}\text { In evaporation } \\
\text { temperature }\end{array}$ & $400,000.00$ & $15,000.00$ & Isotropic & Spherical & 0.0037 & 0.0415 & $49,010.290$ \\
$\begin{array}{c}\log \\
\text { precipitation }\end{array}$ & $400,000.00$ & $37,000.00$ & Isotropic & Gaussian & 1.0380 & 2.1490 & $101,300.432$ \\
\hline
\end{tabular}


Semi-variogram model was created with GS + (Gamma Software) software. The variograms for precipitation, temperature and evaporation are shown in Figures 9(a)-(c).

The variogram parameters were transferred to the GSI environment and the Ordinary Kriging method was used to interpolate the variogram parameters. As a result of this method, distribution maps are shown in Figure 10.

\section{Variograms (Z)}

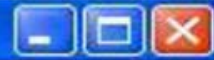

Isotropic Variogram

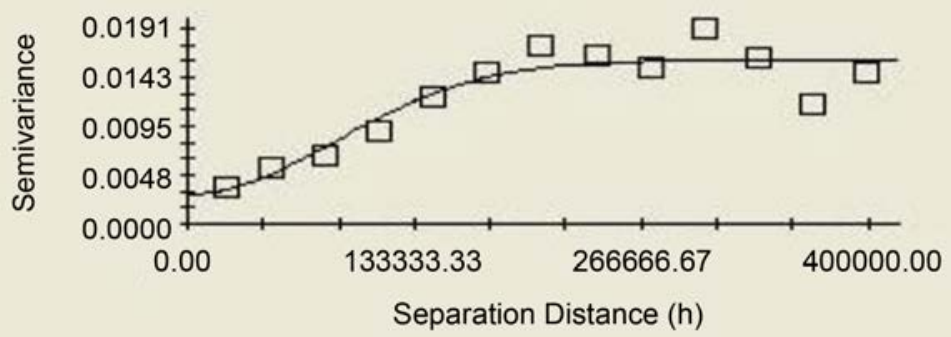

Gaussian model $(\mathrm{Co}=0.003 ; \mathrm{Co}+\mathrm{C}=0.016 ; \mathrm{Ao}=122300.00 ; \mathrm{r} 2=0.866$; $\mathrm{RSS}=3.882 \mathrm{E}-05$

Isotropic +0 Degrees +45 Degrees +90 Degrees $+135 \mathrm{D}+4$

\section{Cloud Scatter}

Right-click to edit, list, print, etc. or click point for variance cloud

(a)

\section{Variograms $(Z)$}

Isotropic Variogram

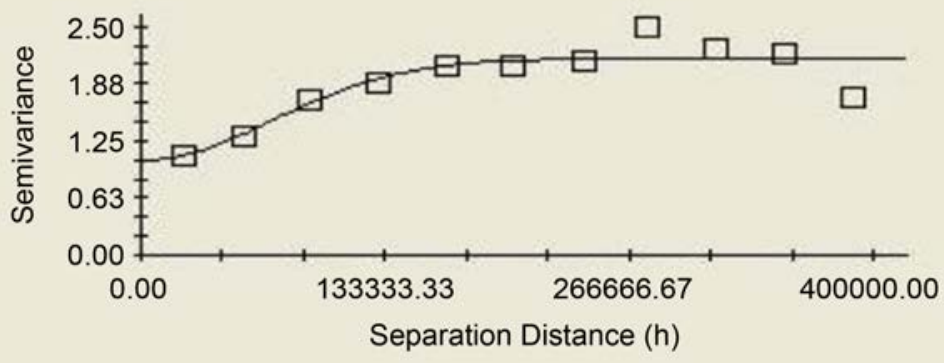

Gaussian model $(\mathrm{Co}=1.038 ; \mathrm{Co}+\mathrm{C}=2.149 ; \mathrm{Ao}=101300.00 ; \mathrm{r} 2=0.812$; $\mathrm{RSS}=0.330$ )

Isotropic +0 Degrees $\frac{+45 \text { Degrees }+90 \text { Degrees }+135 \text { Degrees }}{\text { Cloud Scatter }}$

Right-click to edit, list, print, etc. or click point for variance cloud

(b) 
Isotropic Variogram

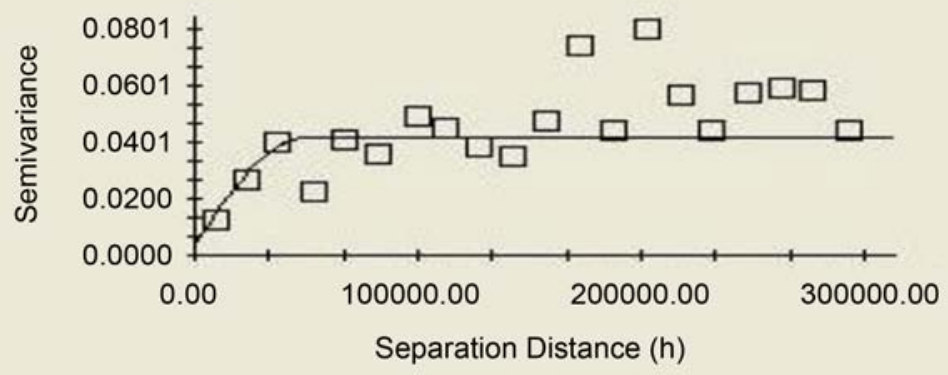

Spherical model $(\mathrm{Co}=0.004 ; \mathrm{Co}+\mathrm{C}=0.042 ; \mathrm{Ao}=49010.29 ; \mathrm{r} 2=0.334$; RSS $=4.176 \mathrm{E}-03$ )

Isotropic $+\frac{+0 \text { Degrees }}{+ \text { Cloud } \text { Scatter }}$

Right-click to edit, list, print, etc. or click point for variance cloud

(c)

Figure 9. Variogram models for precipitation, temperature and evaporation distribution models.

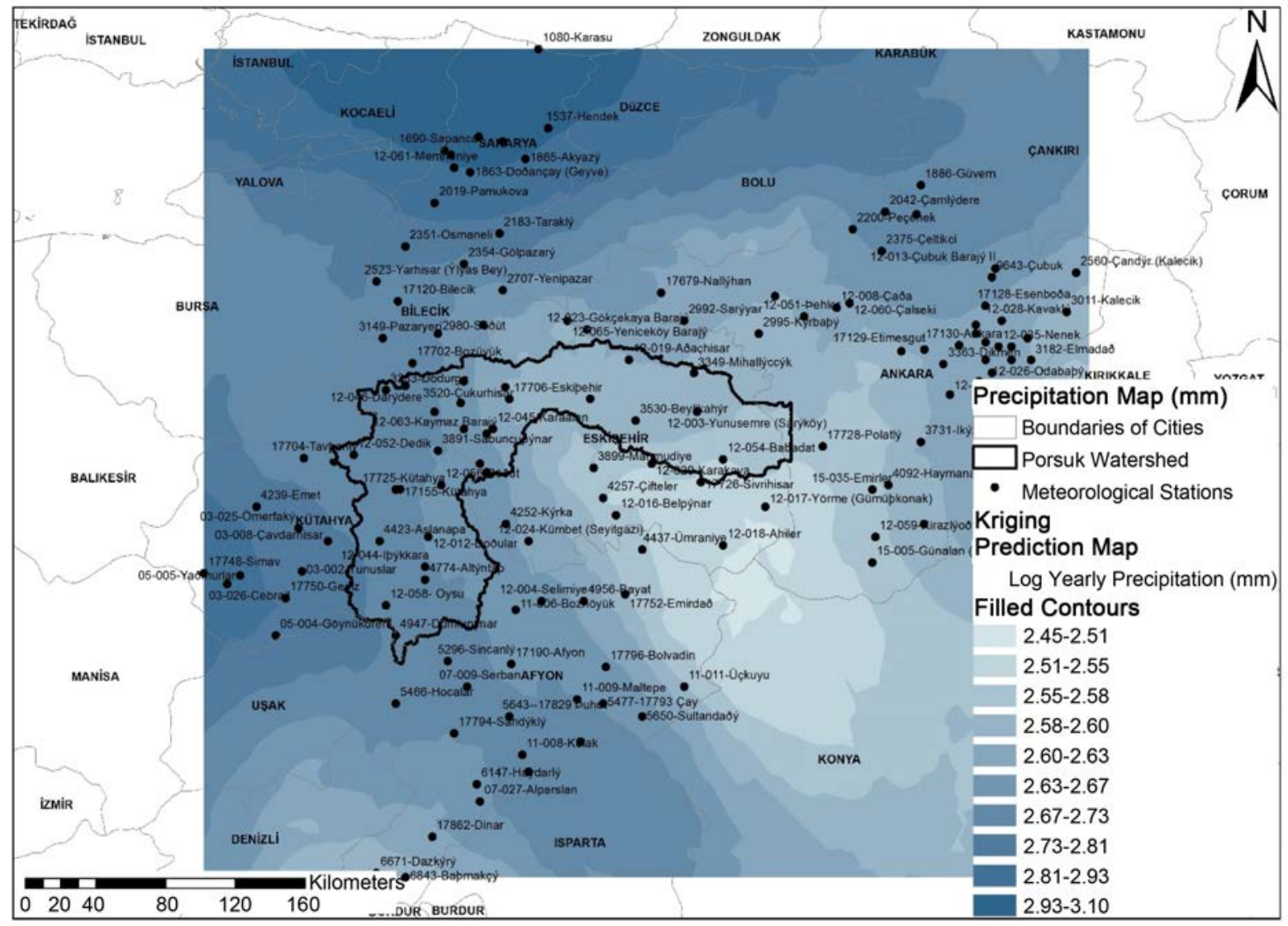

(a) 


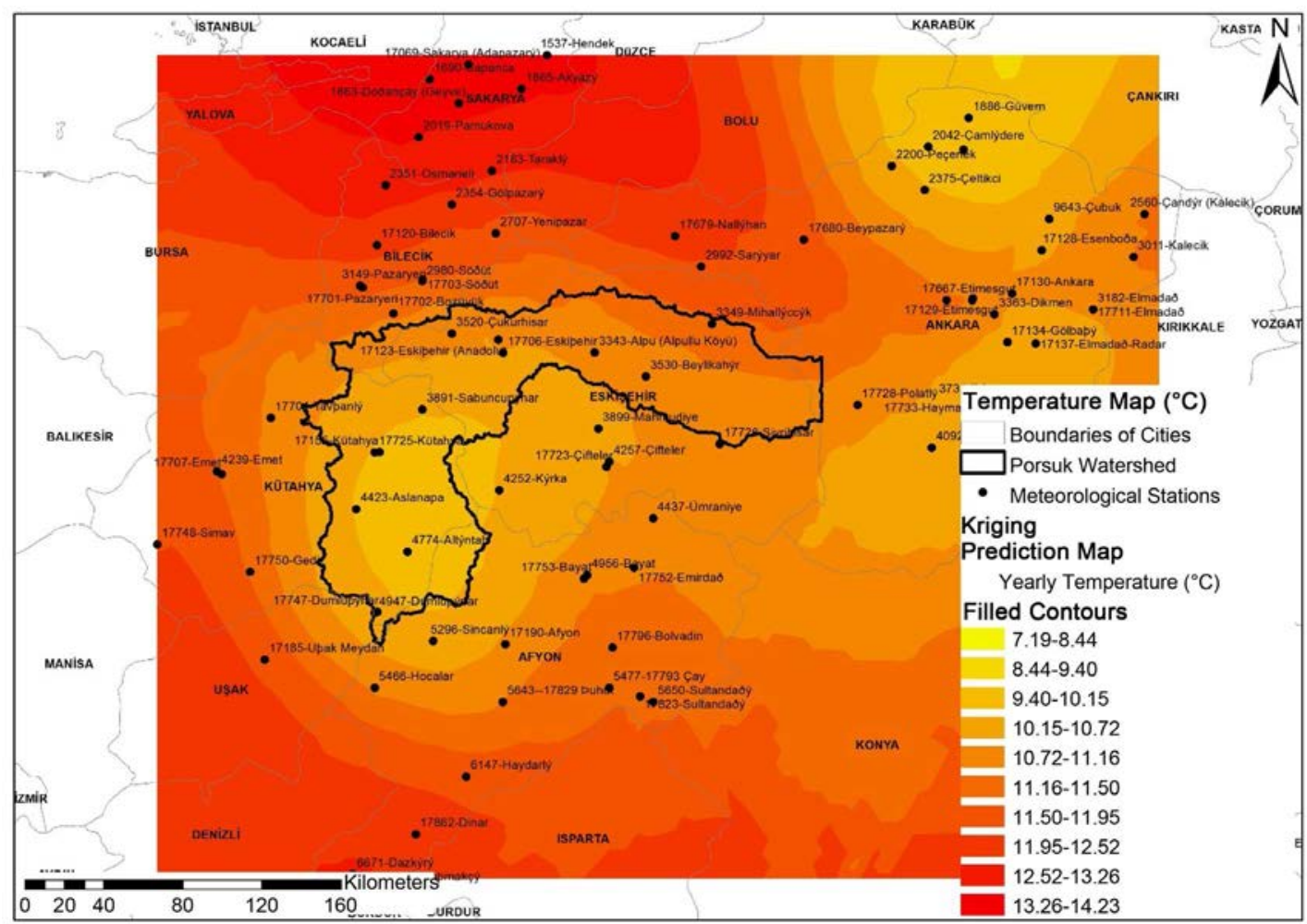

(b)

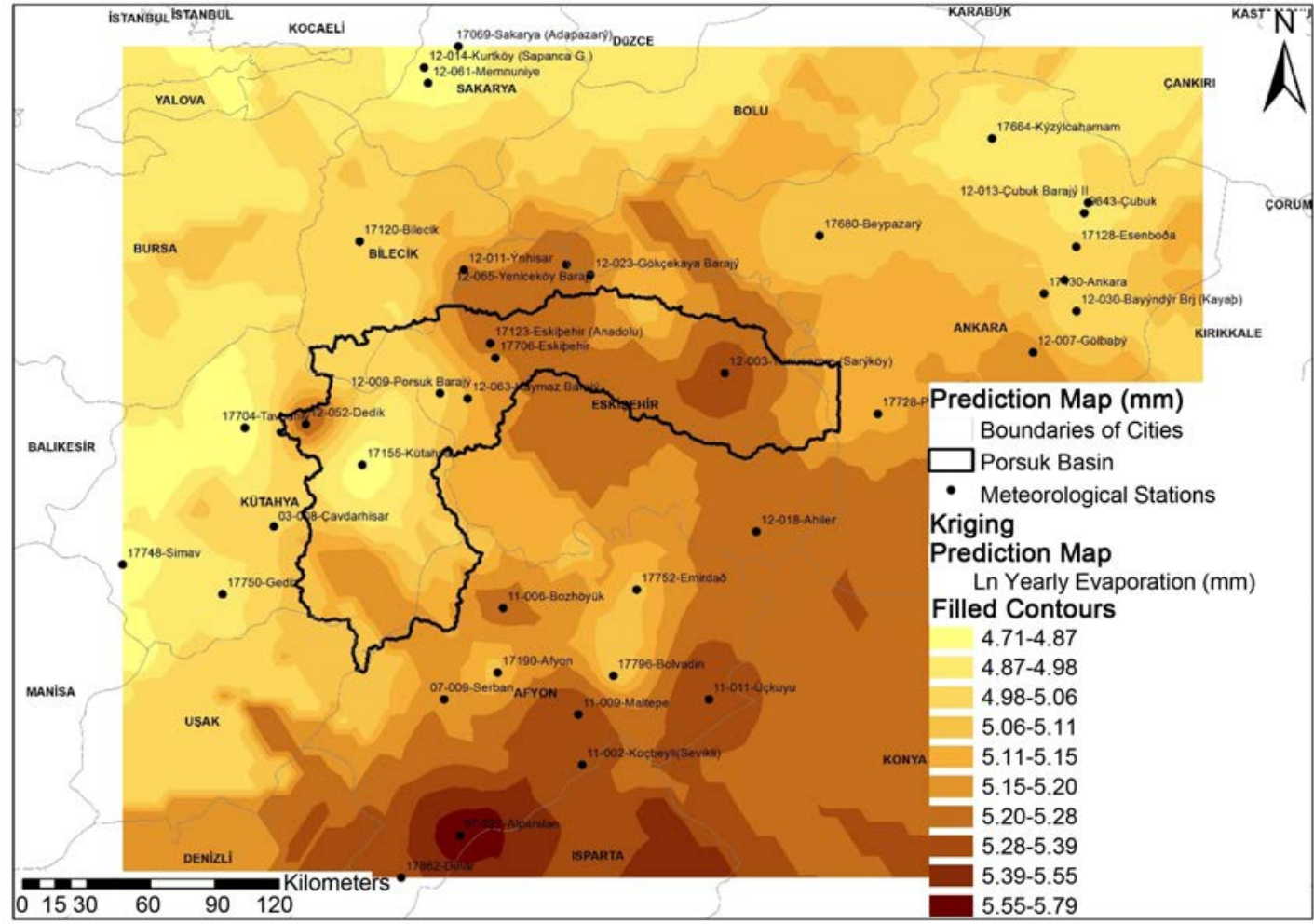

(c)

Figure 10. (a)-(c) Ordinary Kriging model of data distribution. (a) Log precipitation distribution by Ordinary Kriging method. (b) Temperature distribution by Ordinary Kriging method. (c) Ln evaporation distribution by Ordinary Kriging method. 
As we have already done in the IDW method, maps obtained after the estimation are converted into real meteorological values by the raster calculator command (Figures 11(a)-(c)).

\section{Accuracy Analysis of Ordinary Kriging Method}

Randomly selected meteorological observation stations with appropriate spatial distribution to determine the accuracy of the predictions, such as accuracy analysis after IDW interpolation, were selected as control points and precipitation, temperature, evaporation distributions were applied by Ordinary Kriging interpolation method without this data. The actual and estimated results of the selected control stations are compared with $20 \%$ of the number of existing stations and the mean square error (MSE) is determined (Tables 8-10).

The accuracy of the estimates is also dependent on the location of the selected control stations during the accuracy analysis as well as the location in the general data group of the measured value made at that station, and also the distribution of the data source points to the distribution in the working area. If the control station data contains the largest or smallest value of the data set, or if the position of this station is close to the working area, it will not be possible to calculate this station value with high accuracy using other station data. For this reason, determining the control stations during the accuracy analysis is an important component for the correct evaluation of the results of the study.

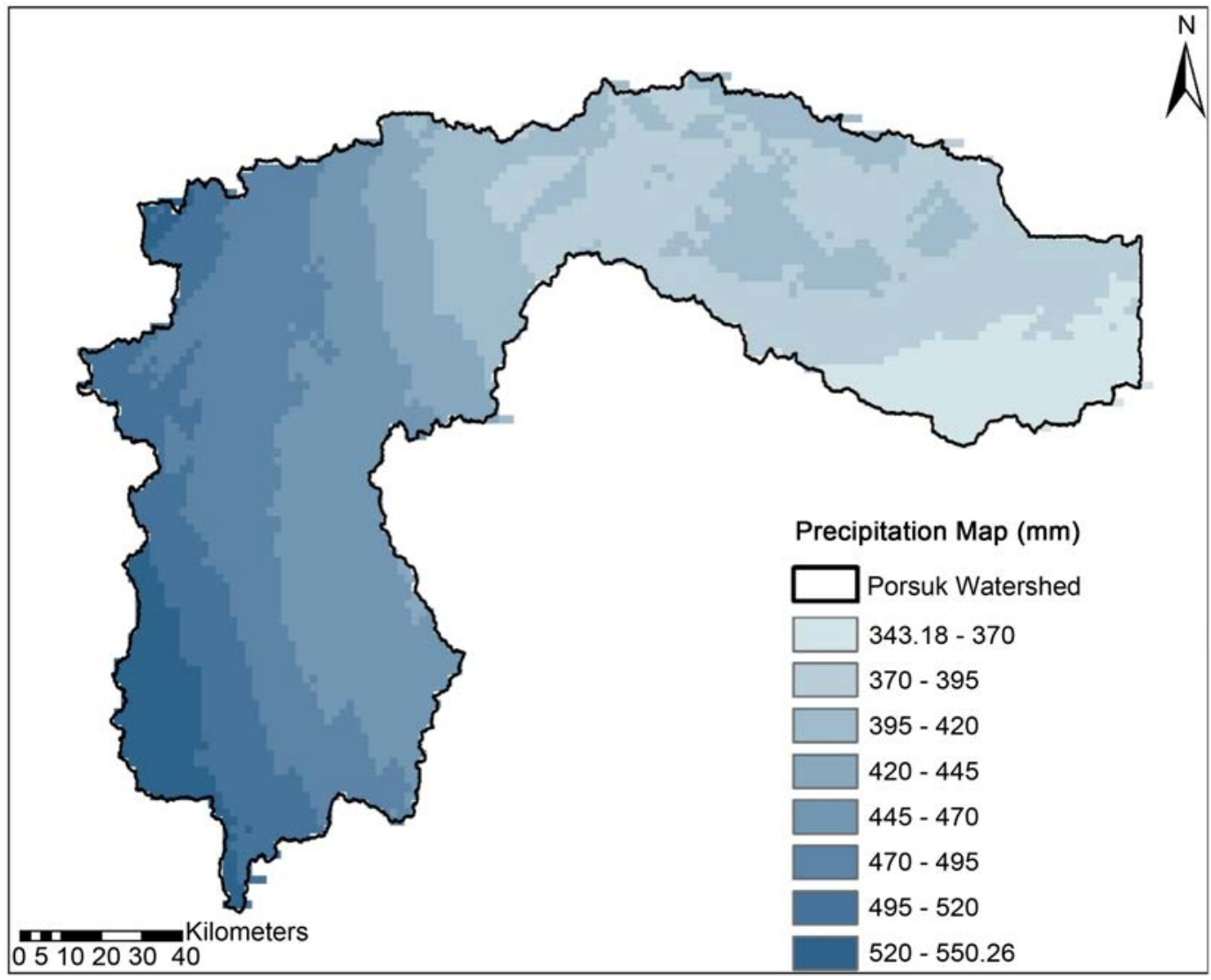

(a) 


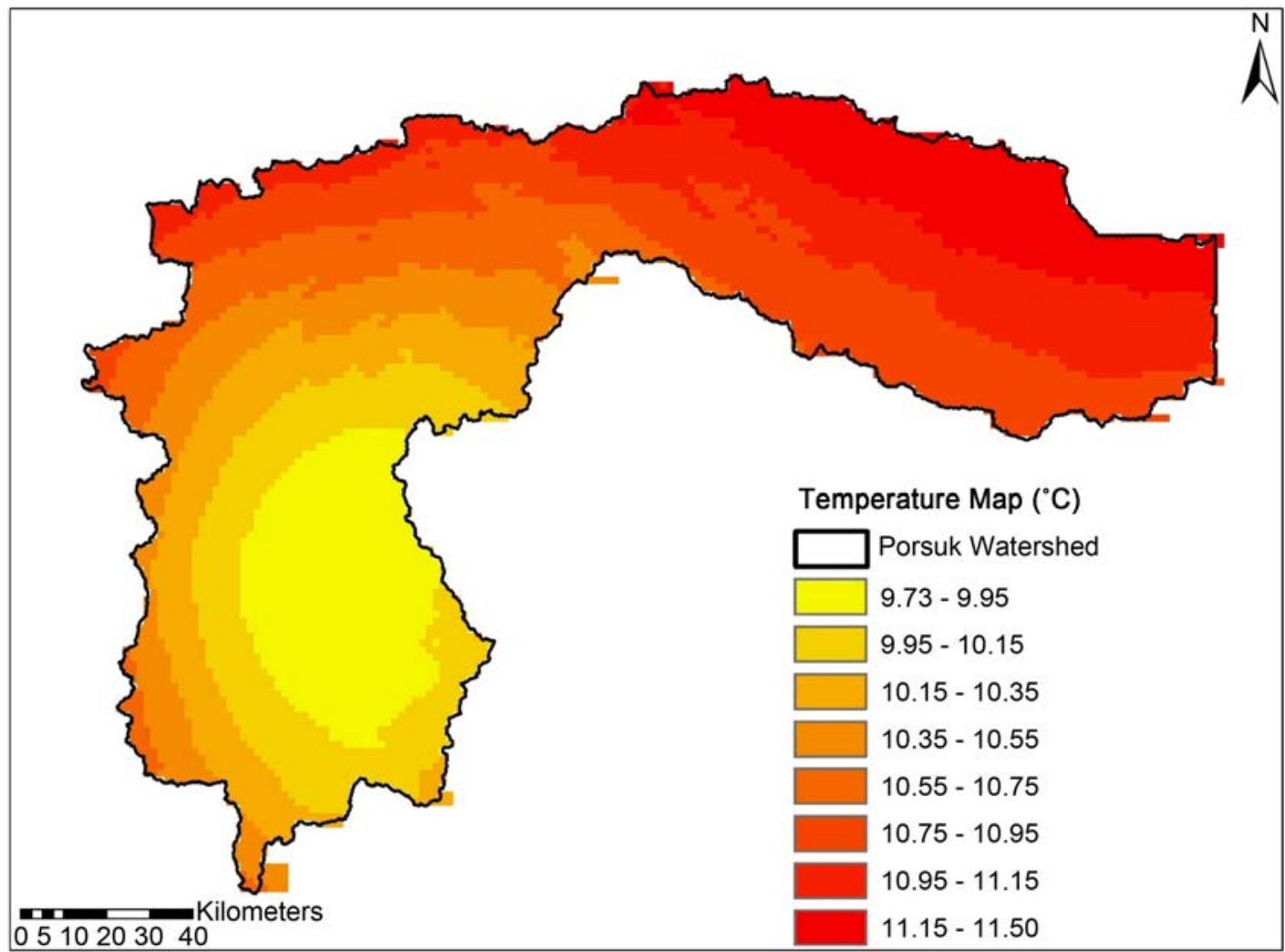

(b)

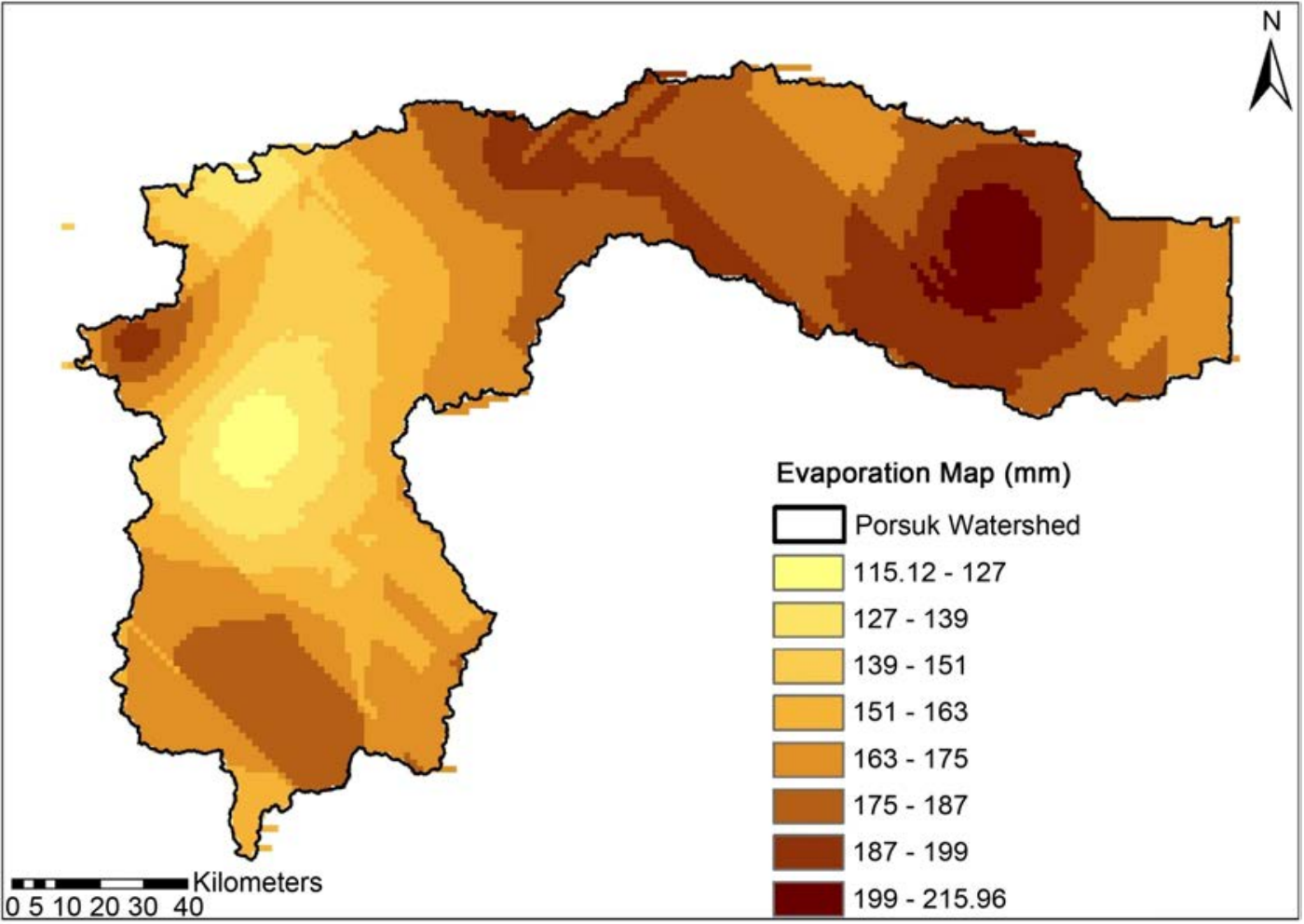

(c)

Figure 11. (a)-(c) Precipitation, temperature and evaporation distribution maps generated by applying Ordinary Kriging method of Porsuk Basin. (a) Precipitation map. (b) Temperature map. (c) Evaporation map. 
Table 8. Real and calculated values of rainfall control stations.

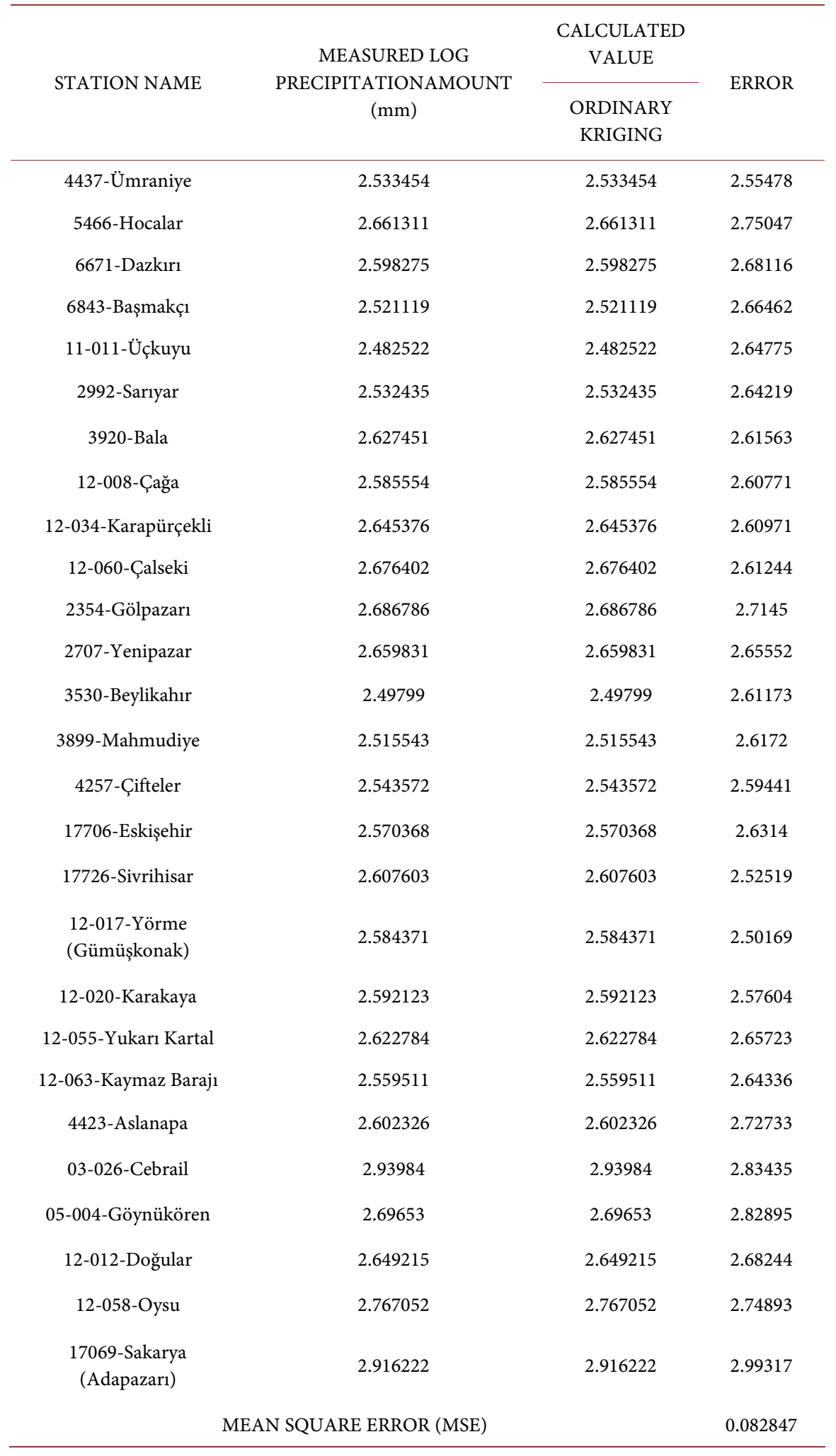

\section{Conclusion}

As a result of the accuracy analyses, the squared mean error values of the estimation 
Table 9. Actual and calculated values of temperature measuring control stations.

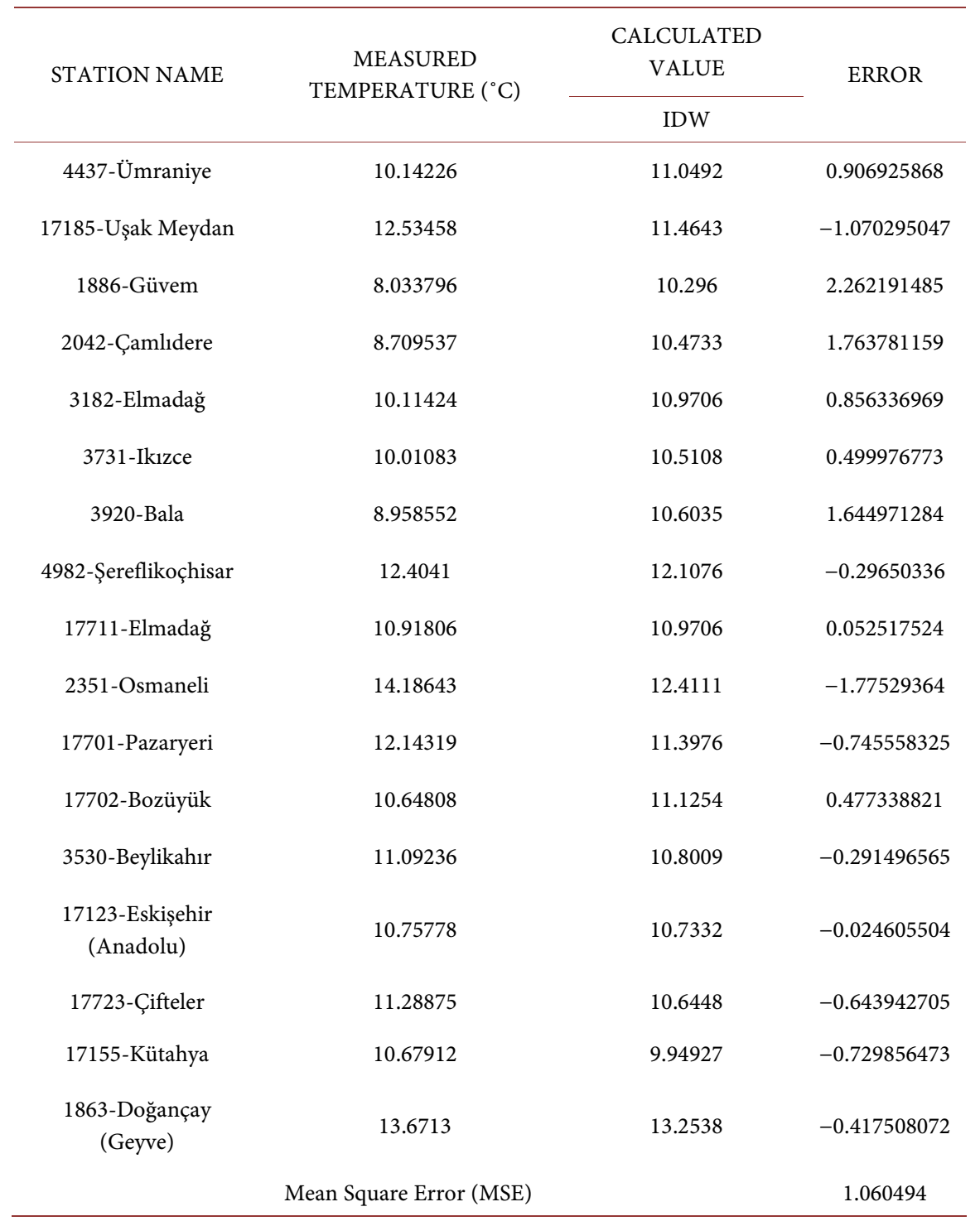

results obtained according to the IDW and Ordinary Kriging method are closest to zero (0) as compared to other methods, as seen in Table 11. In order for the estimation method to be able to produce a reliable result, the data to be used in estimation must first be statistically evaluated. In the study, the meteorological data were analyzed statistically and the values which did not show normal distribution were normalized. Then the normalized data sets are modeled by weighting with the inverse of distance. Estimation results obtained according to normalized values need to be converted to their real values, since they do not have real values. For this purpose, pixel based recycling process has been applied in order to return the data to real values using raster calculator. The accuracy of the obtained models is an important parameter in terms of the reliability of this study. For this reason, accuracy analysis is performed on the models and it is observed that the quadratic mean error values are close to zero. The fact 
Table 10. Actual and calculated values of evaporation control stations.

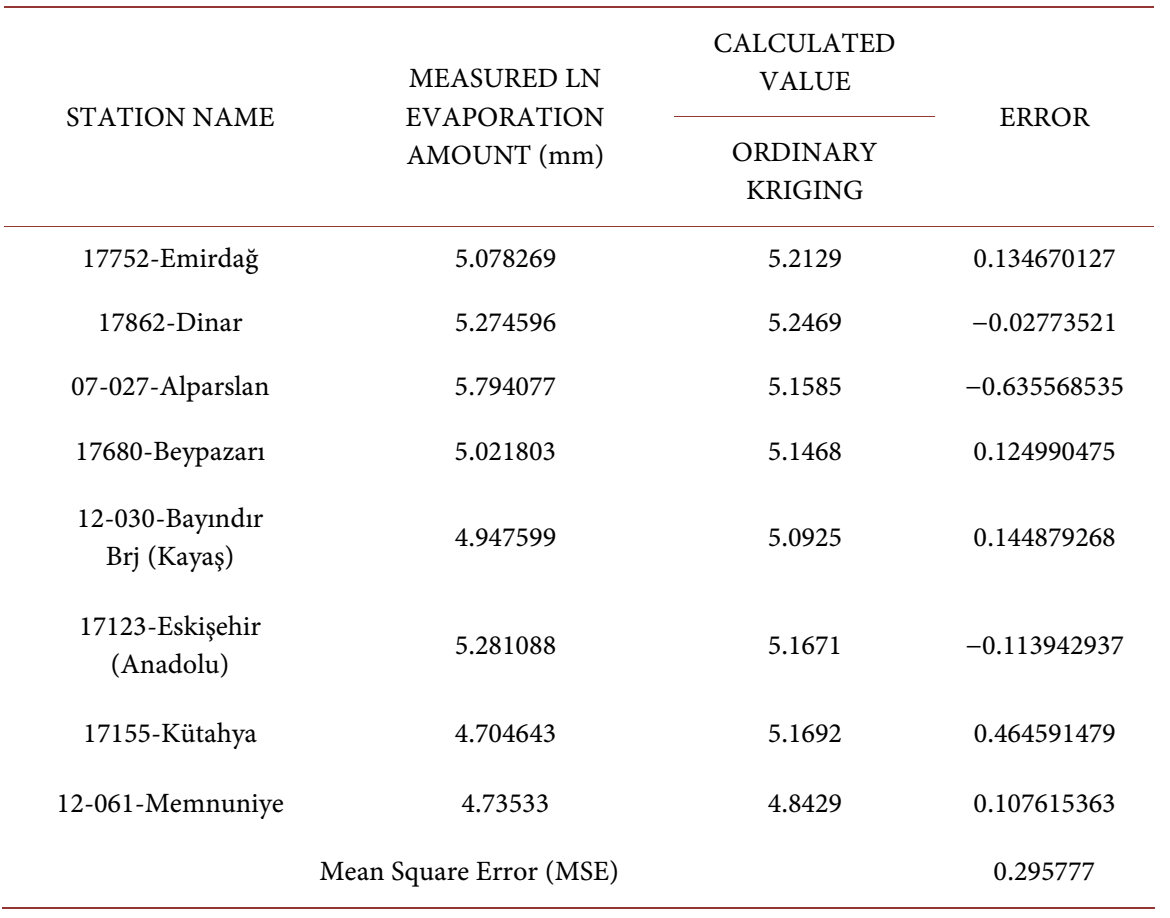

Table 11. MSM values according to IDW and Ordinary Kriging method.

\begin{tabular}{ccc}
\hline & IDW & OK (Ordinary Kriging) \\
\hline log precipitation & 0.08221 & 0.082847 \\
Temperature & 1.204414 & 1.066494 \\
$\ln$ evaporation & 0.261948 & 0.295777 \\
Arithmetic Mean of Quadratic Mean Errors & 0.51619 & 0.48706 \\
\hline
\end{tabular}

that the square mean error values are close to zero is an indication that the accuracy of the obtained models is high and reliable.

\section{Acknowledgements}

This study was supported by Anadolu University Scientific Research Projects Commission within the scope of project number 1506F500.

\section{References}

[1] Şen, Z. (2002) Hidrolojide; Veri İşlem, Yorumlama ve Tasarım., Seminer Notları, Su Vakfı Yayınları, İstanbul.

[2] Nişancı, R., Yıldırım, V. and Yıldırım, A. (2007) Su Havzalarına Yönelik CBS Veri Tabanı Modellemesi: Trabzon Galyan Vadisi Örneği, TMMOB Coğrafi Bilgi Sistemleri Kongresi, Trabzon.

[3] Güler, M. and Kara, T. (2007) Alansal Dağılım Özelliği Gösteren İklim Parametrelerinin Coğrafi Bilgi Sistemleri İle Belirlenmesi ve Kullanım Alanları; Genel Bir Bakış, Ondokuz Mayıs Üniversitesi, Ziraat Fakültesi Dergisi, syf: 322-328. 
[4] Cruetin, J.D. and Obled, C. (1982) Objective Analysis and Mapping Techniques for Rainfall Fields: An Objective Comparison. Water Resources Research, 18, 413-431.

[5] Devlet Meteoroloji İşleri Genel Müdürlüğü (DMİ) (2011) Ankara. https://www.mgm.gov.tr/

[6] BSTS (2004) BSTS/İktisat Terimleri Sözlüğü. http://tdkterim.gov.tr/bts/

[7] Waters, N.M. (1988) Expert Systems and Systems of Experts, Chapter 12. In: Coffey, W.J., Ed., Geographical Systems and Systems of Geography, University of Western Ontario, London, Ontario.

[8] Kahaner, D., Moler, C. and Nash, S. (1989) Numerical Methods and Software, Prentice Hall, Englewood Cliffs.

[9] İnal, C., Turgut, B. and Yiğit, C.Ö. (2012) Jeodezik uygulamalarda jeoit ondülasyonların in belirlenmesinde kullanılan enterpolasyon yöntemlerinin karşılaştırılması, Selçuk Üniversitesi Jeodezi ve Fotogrametri Mühendisliği Öğretiminde 30. Yıl Sempozyumu, 16-18 Ekim 2012, Konya

[10] Trangmar, B.B., Yost, R.J. and Wehara G. (1985) Application of Geostatistic to Spatial Studies of Soil Properties. Advances in Agronomy, 38, 65-91.

[11] Başkan, O. (2004) Gölbaşı yöresi topraklarının mühendislik, fiziksel özellik ilişkilerinde jeoistatistik uygulaması. Ankara Üniversitesi Fen Bilimleri Enstitüsü, Doktora Tezi.

[12] Journel, A.G. and Huijbreegts, CH.J. (1978) Mining Geostatistics, Breau De RecherchesGeologiques Et Miners, France Academic Pres Harcout Brace \& Company, Publishers London, San Diego, New York, Boston, Sidney, Toronto.

[13] Çetin, M. (1996) Jeoistatistiksel yöntem ile nokta ve alansal yağışların saptanması ve stokastik olarak modellenmesi, Doktora Tezi, Çukurova Üniversitesi, Fen Bilimleri Enstitüsü, Adana.

[14] Tercan, A.E. and Saraç, C. (1998) Maden yataklarının değerlendirmesinde jeoistatistiksel yöntemler, T.M.M.O.B. Maden Mühendisleri Odası Yayını, Ankara.

[15] Mert, B.A. (2005) jeoistatiksel analiz için bir bilgisayar programının geliştirilmesi ve Antalya-Akseki-Kızıltaş boksit yatağına uygulanması, Yüksek Lisans Tezi, Çukurova Üniversitesi, Fen Bilimleri Enstitüsü, Adana.

[16] Burrough, P.A. (1991) Sampling Designs for quantifying Map Unit Composition. In: Mausbach, M.J. and L.P. Wilding, Eds., Spatial Variability of Soils and Landforms, SSSA Special Publication Number 28. Soil Science of America, Inc. Madison, 89-127.

[17] Dikici, H. (2001) Toprak biliminde kullanılan bazı jeoistatistik yöntemleri, Tarımda Bilişim Teknolojileri 4. Sempozyumu, 76-81.

[18] David, M. (1988) Handbook of Applied Advanced Geostatistical Ore Reserve Estimation, Elsevier Science Publishing Company, Amsterdam.

[19] Chauvet, P. (1982) The variogram Cloud. In: Jhonson, T.B. and Barnes, R.J., Eds., 17 th APCOM Society of Mining Engineers, New York, 757-764.

[20] Delhomme, J.P. (1978) Kriging in the Hydrosciences. Advances in Water Resources, 5, 251-266. https://doi.org/10.1016/0309-1708(78)90039-8

[21] Vieira, S.R., Hatfield, J.L., Nielsen, D.R. and Biggar, J.W. (1983) Geostatistical Theory and Application to Variability of Some Agronomical Properties. Hilgardia, 51, 1-75. https://doi.org/10.3733/hilg.v51n03p075

[22] Oliver, M.A. and Webster, R. (1991) How Geostatistics Can Help You. Soil Use and 
Management, 7, 206-217. https://doi.org/10.1111/j.1475-2743.1991.tb00876.x

[23] İnal, C. and Yiğit, C.Ö. (2003) Jeodezik uygulamalarda kriging enterpolasyon yönteminin kullanılabilirliği, TUJK 2003 Yılı Bilimsel Toplantısı Coğrafi Bilgi Sistemleri ve Jeodezik Ağlar Çalıştayı 24-25-26 Eylül, Konya. 